\title{
Crítica ao apagamento das mulheres no ensino industrial: a história da inserção feminina na Escola Técnica Federal do Espírito Santo (1950-1970)
}

\author{
Marcelo Lima' (D) \\ Lisia Nicoliello Cariello" (D) \\ Rosângela Aquino da Rosa Damasceno"I
}

\section{RESUMO}

Analisamos a inserção da mulher na educação e na sociedade brasileira por meio de seu acesso e sua permanência em cursos de ensino industrial em uma instituição da rede federal no período de 1950 a 1970. Por meio da comparação e do cruzamento das fontes, questionamos a versão oficial sobre o início da participação do sexo feminino no conjunto do corpo discente, que teria ocorrido na década de 1970, quando a instituição já se denominava Escola Técnica Federal do Espírito Santo. Entretanto, operando metodologicamente com a intertextualidade de documentos e fotografias, de um lado, evidenciamos as tentativas de apagamento dos processos de exclusão do sexo feminino desse contexto histórico e, por outro, concluímos que o início da inserção feminina já ocorrera bem antes, ainda nos anos de 1950, quando a unidade de ensino ainda se nomeava Escola Técnica de Vitória.

\section{PALAVRAS-CHAVE}

inserção feminina; historiografia; fotografia; Escola Técnica Federal do Espírito Santo.

'Universidade Federal do Espírito Santos, Vitória, ES, Brasil.

"Universidade Federal Fluminense, Niterói, RJ, Brasil.

"'Instituto Federal de Educação, Ciência e Tecnologia do Rio de Janeiro, Rio de Janeiro, RJ, Brasil. 


\title{
CRITICISM TO THE DELETION OF WOMEN IN INDUSTRIAL EDUCATION: THE HISTORY OF FEMALE INSERTION IN THE FEDERAL TECHNICAL SCHOOL OF ESPIRITO SANTO (1950-1970)
}

\begin{abstract}
We analyzed the insertion of women in education and in Brazilian society, based on their access and permanence in industrial education courses at a federal institution in the period from 1950 to 1970 . By comparing and crossing the sources, we question the version official about the beginning of female participation in the group of students that would have occurred in the 1970s when the institution was already called Federal Technical School of Espírito Santo. However, operating methodologically with the intertextuality of documents and photographs, on the one hand, we highlight attempts to erase the processes of exclusion of women in this historical context and, on the other hand, we conclude that the beginning of female insertion had occurred well before, even in the years 1950, when the teaching unit was still named Escola Técnica de Vitória.
\end{abstract}

KEYWORDS

female insertion; historiography; photography; Federal Technical School of Espírito Santo.

\section{CRÍTICA A LA SUPRESIÓN DE MUJERES EN LA EDUCACIÓN INDUSTRIAL: LA HISTORIA DE LA INSERCIÓN FEMENINA EN LA ESCUELA TÉCNICA FEDERAL DE ESPIRITO SANTO (1950-1970)}

\section{RESUMEN}

Analizamos la inserción de las mujeres en la educación y en la sociedad brasileña, a partir de su acceso y permanencia en los cursos de educación industrial en una institución federal en el período de 1950 a 1970. Al comparar y cruzar las fuentes, cuestionamos la versión oficial sobre el inicio de la participación femenina en el grupo de estudiantes que habría ocurrido en la década de 1970 cuando la institución ya se llamaba Escola Técnica Federal do Espírito Santo. Sin embargo, operando metodológicamente con la intertextualidad de documentos y fotografías, por un lado, destacamos los intentos de borrar los procesos de exclusión de las mujeres en este contexto histórico y, por otro lado, concluimos que el inicio de la inserción femenina ya se había dado mucho antes, incluso en los años 1950, cuando la unidad didáctica todavía se llamaba Escola Técnica de Vitória. 


\section{INTRODUÇÃO}

O debate teórico-metodológico sobre o uso da fotografia como fonte histórica no contexto da inserção feminina no ensino industrial passa, necessariamente, pela relação entre as concepções de história e de fotografia. Também consiste em campo da articulação entre o conhecimento historiográfico e a expressão estética do registro visual da existência social humana. Incorporando alguns elementos do campo da história desenvolvidos por Benjamin (1987), Ginzburg (1989), Bloch (2001), Hobsbawm (2003) e Fontes (2014), em diálogo com o materialismo histórico-dialético, por meio de Malerba (2006) e Saffioti (2013), procuramos problematizar versões hegemônicas da periodização histórica vigente da inserção feminina no ensino industrial, no período entre 1940 e 1970, na rede federal de ensino profissional.

Tomamos como objeto de análise a trajetória histórica do atual Instituto Federal do Espírito Santo (IFES), que surgiu em 1910 como Escola de Aprendizes Artífices do Espírito Santo, produto da política nacional do então presidente Nilo Peçanha, que em 1909 deu origem à rede federal de educação profissional e tecnológica. Foi transformada em Escola Técnica de Vitória (ETV) em 1942 para mais tarde, em 1965, vir a ser denominada Escola Técnica Federal do Estado do Espírito Santo (ETFES). Após sua denominação mudar de novo em 1998 para Centro Federal de Educação Tecnológica do Espírito Santo, por fim foi refundada em 2011 como IFES, parte integrante da rede federal de ensino, e assim permanece até hoje. Operando com os conceitos de mediação de Ciavatta (2004), de intertextualidade de Mauad (2008) e de ideologia de Kossoy (2000), aplicados ao objeto fotografia, intencionamos apontar alguns dos limites da validade das informações presentes nas imagens fotográficas, relativizando seu valor como fonte histórica em cotejamento com outras fontes documentais sobre o processo educacional no espaço-tempo em discussão.

Para analisar a inserção social da mulher na história do Brasil, tomamos como base o trabalho de Saffioti (2013), que destaca o papel histórico da educação no processo de constituição da desigualdade entre homens e mulheres e explica como, no processo histórico, se desenvolve e se articula o acesso das mulheres ao trabalho e à educação para definir, impondo, mantendo, aprofundando e/ou reproduzindo em cada fase, os papéis mais ou menos distintos entre homens e mulheres na sociedade brasileira.

Para a autora, no Brasil Colônia, e mesmo no Império, quando a vida social e econômica se situava nos espaços rurais e a vida da mulher estava restrita ao espaço privado, a oferta escolar para os contingentes femininos era residual (em baixa quantidade e em proporção menor em relação aos homens), segregada (confinada a determinados espaços sem coeducação), privada (sem estrutura pública universal), religiosa (em espaços católicos e protestantes), assistencialista (em espaços como orfanatos) e limitada (atendendo apenas aos níveis mais elementares de instrução com viés de preparação para o trabalho doméstico). Mas quando se aprofunda e se intensifica, no Brasil como um todo ou em certos espaços tidos como mais desenvolvidos, a combinação dos elementos constitutivos da inserção social, cultural e econômica da mulher, sua condição vai se alterando. 
Conforme Saffioti (2013), com o advento da coeducação ${ }^{1}$, apesar das forças contrárias, na medida em que se desenvolvia a oferta escolar, um número crescente de mulheres passou a ter acesso à instrução, resultando na progressiva redefinição dos papéis sociais de homens e mulheres e de maior equiparação das relações entre os sexos. Mas a autora alerta que esse processo não foi linear nem progressivo, desenvolvendo-se em passos lentos e com bloqueios e reações contrárias. Até 1930, a frequência de meninas no ginásio era muito pequena, não apenas em virtude da escassez desse tipo de instituição educacional, porém sobretudo pela baixa implementação do regime de coeducação, que muitas vezes destinava vagas sobrantes às mulheres, com preferência às meninas de menor idade (Azevedo, 1964 apud Saffioti, 2013).

No ensino profissional, contexto específico deste estudo, a inserção feminina, já antes da década de 1930, ocorria em favor de uma formação semiprofissional segregada a atividades domésticas ou ligadas a música, costura, chapelaria ou vestuário, em geral ocorrendo em espaços femininos tais quais conventos, educandários de meninas etc. Mas aqui nos interessam como isso se deu e, sobretudo, a reação aos primeiros movimentos de democratização da inserção feminina nos espaços predominantemente masculinos, fossem de produção industrial, fossem de formação profissional, associados tanto à indústria como às escolas de ensino industrial.

Segundo Saffioti (2013), a inserção mais tardia no ensino industrial, ou mesmo no trabalho industrial, não representou a superação da condição estrutural de subalternidade da mulher na sociedade brasileira. De todo modo, por um lado, o atraso da democratização das oportunidades educacionais para a mulher é também explicado pelas numerosas amarras à disseminação generalizada da coeducação, e, por outro, a conservação de espaços produtivos como exclusivos dos homens serviu para manter ainda mais arcaicas e profundamente desiguais as relações entre homens e mulheres no Brasil.

Nesse sentido, sem atribuir ao trabalho industrial o condão de igualar mulheres e homens por realizarem trabalho complexo mais valorizado na sociedade, mas considerando a inserção num mundo educacional tipicamente masculino, importante reduto do machismo e da exclusão das mulheres, observamos que analisar pela historiografia os momentos em que essa inserção se deu e como ocorreu é relevante do ponto de vista histórico e historiográfico. Intencionamos demonstrar a maneira como a memória oficial de uma instituição em nível local, a exemplo de outras em nível nacional ${ }^{2}$, tende a esconder como as instituições reagiram negativamente às primeiras tentativas de democratização do acesso das mulheres ao ensino, em geral, e ao ensino industrial, particularmente.

1 Com a reforma educacional no município da corte de Leôncio de Carvalho instituída pelo Decreto no 7.247, de 19 de abril de 1879, admitiu-se a coeducação (Moacyr, 1936 apud Saffioti, 2013). Segundo o parágrafo $3^{\circ}$ do artigo 4 da lei, "nas escolas do $1^{\circ}$ grau existentes ou que se fundarem, para o sexo feminino, serão recebidos alunos até a idade de 10 anos" (Brasil, 1879).

2 Safiotti (2003) cita Ruy Barbosa, que se manifestou negativamente sobre a coeducação, atribuindo-lhe apenas a função de economia de recursos. 
Em nossa hipótese, houve um processo de apagamento da experiência concreta de inserção inicial das mulheres no espaço-tempo específico em análise, visto que a memória oficial trata o tema negando tais fatos históricos para não ter de explicar como se deu o processo. Desse modo, as primeiras tentativas de absorção do sexo feminino foram tomadas institucionalmente como inexistentes ou malsucedidas, e atribuíram-se as causas às próprias educandas, que não teriam manifestado "pendores para o ofício", o que só pode ser superado por um processo detalhado de reconstrução historiográfica e de problematização da documentação disponível. Para esse fim, o uso de apenas alguns documentos não é suficiente. $\mathrm{O}$ cruzamento de imagens fotográficas com registros escolares, tomados como fontes históricas primárias no seu conjunto, como ensinam Bloch (2001) e Mauad (2008), nos ajudou a perceber como se deu o objeto historiográfico em tela.

As fontes secundárias, no entanto, alimentaram uma memória oficial, que serviu para ocultar as tentativas iniciais de inserção das mulheres, apagando também as práticas de exclusão alicerçadas nos valores da masculinidade e da meritocracia, ainda presentes na instituição, exemplo atual de qualidade de educação pública no país.

\section{DEBATES TEÓRICO-METODOLÓGICOS}

Com base nos pressupostos do materialismo histórico-dialético, base teórico-metodológica de nossas análises, tomamos a contradição capital × trabalho, na sua interface com a questão de gênero, para delinear criticamente a memória oficial da trajetória histórica da emergência da presença feminina numa importante instituição de ensino industrial.

Organizando fontes históricas com vistas à produção de uma historiografia estruturada, em procedimentos de análise documental de imagens e de registros escolares da centenária instituição, buscamos operar com uma concepção de história tomada como método e como processo, na qual o fenômeno em análise é problematizado no seu movimento de ser e no seu vir-a-ser, tendo em vista sua gênese e seu desenvolvimento. Para essa concepção, a investigação histórica toma os registros de imagens e do fluxo escolar como vestígios que possibilitam a reconstituição indutivo-analítica do movimento do real. Nesse viés, a história como produção social da existência humana e como método de pesquisa se situa ao nível de representação pelo pensamento, pela memória e pela escrita da história em que os sujeitos sociais envolvidos são produzidos e produtores da realidade social e histórica (Malerba, 2006).

Assim, escrever a história é reconstruir os fenômenos sociais com base nos vestígios acessíveis pelo pesquisador, cujas conclusões são sempre parciais, pois dependem das fontes utilizadas e das perguntas feitas pelo historiador. Por essa razão, toda história é história do tempo presente, posto que o historiador questiona as fontes influenciado pelas questões que afligem a sociedade de seu tempo, para gerar uma "verdade histórica", sempre em processo de afirmação e validação (Hobsbawm, 2003). 
De acordo com Fontes (2014, p. 189), “considerar a verdade como processo é admitir que tendemos a ela, mas que ela jamais será terminada. Significa também admitir que o contraditório exige discussão e debate e não imposição". Logo, conforme a história se desenrola, mudam-se as perguntas feitas às fontes, descobrem-se novos documentos, e transformam-se as perspectivas históricas. Para essa operação, o pesquisador deve olhar de maneira crítica e questionadora para as fontes, e, com a fotografia, não há de ser diferente.

No caso em tela, destacamos a fotografia como fonte histórica, mas, em termos metodológicos, o seu uso tem limites, assim como a verdade que nela se revela, pois consideramos que todo vestígio precisa ser comparado a outros.

A noção de fonte histórica deve ser problematizada à luz de uma crítica que a considere como suporte de práticas sociais, superando a visão ingênua de que as fontes contêm o passado, e se revelam ao olhar do presente, por sua pura existência. Toda fonte histórica é o resultado de uma operação histórica (Certeau, 1979). Não fala por si só, é necessário que perguntas lhe sejam feitas e que se leve em conta a sua natureza de artefato e de objeto da cultura material, associado à uma função social e a sua trajetória pelos tempos. (Mauad, 2008, p. 21)

Essa reflexão leva-nos a pensar sobre a relação entre fotografia e verdade. Por muito tempo - e até hoje, em alguns casos - a fotografia foi tida como um objeto de comprovação da verdade. Todavia, essa ideia acaba por reduzi-la e limitá-la. Partindo da ideia de que a fotografia é uma representação elaborada cultural, estética e tecnicamente, Kossoy (1998) defende que a imagem fotográfica tem múltiplas faces e realidades: a primeira, mais evidente, interior, uma realidade própria; e a segunda, exterior, intencional.

A fotografia tem uma realidade própria que não corresponde necessariamente à realidade que envolveu o assunto, objeto do registro, no contexto da vida passada. Trata-se da realidade do documento, da representação: uma segunda realidade, construída, codificada, sedutora, de forma alguma ingênua, inocente, mas que é, todavia, o elo material do tempo e do espaço representado, pista decisiva para desvendarmos o passado. (Kossoy, 2000, p. 22)

Semelhantemente ao argumento de Kossoy (2000), Kosik (1976) defende que um fenômeno indica a essência, mas também a esconde. A essência é mediata ao fenômeno, não sendo imediatamente dada à compreensão, e manifesta-se em algo diferente do que é, apesar de ser um componente da realidade ao lado da aparência. Constitui-se, ainda, de processos mais complexos, com significados diversos, dependendo dos seres sociais e da dinâmica dos fenômenos envolvidos. Assim, conhecer um objeto é revelar sua estrutura social. Ciavatta (2004) argumenta que é imprescindível

ir além das aparências, captar o mundo das mediações, dos processos sociais (técnicos, econômicos, políticos, ambientais, científicos etc.), da essência oculta do fenômeno. São relações articuladas que são reconstruídas no nível do conhecimento histórico, dentro de determinada totalidade social que faz parte do mundo objetivo. (Ciavatta, 2004, p. 46) 
E aponta caminhos:

A perspectiva histórica das mediações implica incluir como propriedades do objeto, as conexões que o determinam em situações de tempo e espaço determinado, única forma de encontrar a explicação sem cair no esquema abstrato de uma relação mecânica. Trata-se de não perder de vista o significado que o objeto tem não apenas como singularidade, mas também como particularidade. A mediação é passo necessário para descrever a particularidade do objeto, a relação do aparente, singular ou contingente, com o processo mais compreensivo que o determina. (Ciavatta, 2004, p. 46)

$\mathrm{Na}$ esteira desse pensamento, podemos conceber a fotografia como mediação, como exemplo de objeto que mostra e esconde a realidade, num duplo movimento. Enquanto objeto, a fotografia é simultaneamente imagem/documento e imagem/ monumento. Para Le Goff (1996), é produção material coletiva que carrega intencionalidades de construção de determinada memória, que abriga certos valores, ideias, tradições e comportamentos, e não outros. Consiste, portanto, em imagem/ monumento, em registro produzido como algo a ser perpetuado. Como imagem fotográfica, mais do que um fragmento congelado e espontâneo de um acontecimento passado, resulta da intromissão consciente do fotógrafo que a produziu. Para Kossoy (1998), três são os elementos essenciais para a realização de uma fotografia: o assunto, o fotógrafo e a tecnologia. O primeiro é o que merece ser fotografado. O segundo tem influência direta no resultado do processo, pois é ele que dá a perspectiva, o ângulo etc. O terceiro, além de dar pistas sobre a historicidade do objeto fotográfico, também influencia no resultado obtido.

Atualmente, vivemos um processo de banalização da fotografia, pois temos em mãos smartphones capazes de registrar inúmeras poses, ao contrário do que era comum à época dos daguerreótipos, em que os sujeitos fotografados tinham de ficar parados por alguns minutos para a imagem ser captada. Machado (1998) traz algumas problematizações sobre as tecnologias mais recentes, defendendo que essas mudanças causam impacto no conceito tradicional da fotografia, alterando o ato de fotografar, bem como o consumo dessas fotografias.

O autor defende que fotografia é o registro de luz sobre uma película revestida quimicamente e que os grãos fotoquímicos convertidos em unidades de cor e brilho matematicamente controláveis são chamados pixels. Encara, portanto, as mudanças tecnológicas enquanto pixelização, buscando jogar luz nos processos de modificação da fotografia, como a edição. É imprescindível recordar, entretanto, que técnicas não eletrônicas são usadas para editar fotos há muito tempo.

Além da reflexão da relação entre fotografia e verdade, a discussão acerca da edição fotográfica também abre margem para pensar a relação fotografia e ideologia. Até a banalização — não no sentido negativo - dos celulares com câmeras fotográficas, a fotografia era um artefato da elite. Ou seja, só eram fotografadas as famílias com quem (e como) se era interessante fotografar. Fotografar era uma escolha, como também o é hoje em dia, pois escolhemos o que registrar, como e quando vale o registro (mesmo que sejam muitos). O uso da fotografia como fon- 
te histórica está sujeito a inúmeras escolhas conscientes e direcionadas, tanto na produção quanto no manuseio e/ou na preservação de documentos que vão servir, como afirma Le Goff (1996), como monumento, constituindo intencionalmente uma memória hegemônica. No contraponto à questão da memória evidenciada por documentos na forma de imagens preservadas como monumentos, há o caso em que a memória é intencionalmente apagada ou esquecida, ou mesmo destruída.

Benjamim (1987) e Ginzburg (1989), no campo da história, e mesmo Santos (1988), no campo da sociologia, defendem a reconstrução de uma história "a contrapelo", que valoriza narrativas contra-hegemônicas, ou uma espécie de sociologia das ausências, que cognitivamente se insere na ideia contracorrente de que, produzindo um tipo de inversão epistemológica e que toma o ausente, ou mesmo o indício, no contraponto aos dados convergentes e dominantes, majoritariamente se confirma a versão dos vencedores para apontar dados divergentes que destacam a versão dos vencidos, mostrando que outra narrativa baseada em outro percurso historiográfico é possível.

\section{A INSERÇÃO DA MULHER NO ENSINO INDUSTRIAL: CONTRIBUIÇÃO DA INTERFACE DA FOTOGRAFIA E OUTROS TIPOS DE FONTES PARA ANÁLISE DA PRESENÇA FEMININA}

Para analisar a inserção da mulher na sociedade brasileira — de modo mais específico, no ensino industrial - destacamos elementos históricos do período de 1950 a 1970 que, de um lado, revelam o início da superação de sua exclusão no acesso à educação e ao trabalho, mas, de outro, evidenciam as reações contrárias nos espaços-tempos masculinizados do ensino industrial, criticando a historiografia oficial, para além do uso da fotografia como fonte histórica.

\section{A COEDUCAÇÃO NO BRASIL: DA LEI À PRÁTICA NO SÉCULO XX}

Para tratar do tema da inserção feminina no trabalho industrial e no ensino industrial no século XX, em função de nosso acesso às fontes, escolhemos sinalizar o movimento que vai, dos elementos da realidade nacional aos aspectos da realidade local, delineando-se no IFES, cuja origem remonta às escolas de aprendizes artífices criadas no Brasil em 1909 e que no Espírito Santo passaram a funcionar no começo de 1910 (Sousa, 2019).

Segundo dados de Brasil (2009), tais instituições, originadas nas casas dos meninos desvalidos, tinham seu público constituído de crianças do sexo masculino que, compulsoriamente, eram recolhidas nos espaços urbanos para fins de implementação de um projeto eugênico, com o pretexto de formar para o trabalho industrial. Eram unidades de ensino que ministravam conteúdo do ensino primário, rudimentos de desenho, e formavam para o trabalho artesanal, mas que se assemelhavam mais às casas de internação, cujo público-alvo era a infância abandonada a ser atendida por um projeto educacional de caráter correcional e assistencialista.

Segundo Saffioti (2013), nos anos de 1940, a legislação educacional, apesar de ensaiar algum avanço na coeducação, quer no ensino primário, quer no secun- 
dário, ou mesmo no ensino industrial (ainda extremamente masculinizado), nas suas contradições internas e na sua efetivação, não mudou de imediato o quadro de exclusão feminina do acesso à educação. O Decreto-Lei no 4.244, de 1942 (apud Saffioti, 2013), por exemplo, ao definir o "ensino secundário feminino", discriminou as mulheres e desferiu um golpe no processo de aceitação da coeducação em curso. Sem instituir a educação segregada para os dois sexos, sugeria que a educação da mulher se fizesse em classes especiais, isto é, em classes femininas. No artigo 25, título III, afirma-se: "Nos estabelecimentos de ensino secundário frequentado por homens e mulheres, será a educação destas ministradas, sempre que possível, em classes exclusivamente femininas" (conforme versão presente no Decreto-Lei n ${ }^{\circ}$ 8.347, de 1945 apud Saffioti, 2013, p. 320).

Os dados da autora informam que, ainda em 1955, a exclusão do acesso à educação escolar era mais evidente no caso das mulheres, pois na população brasileira havia $51,65 \%$ de analfabetos, dos quais $23,44 \%$ eram homens e $28,21 \%$ mulheres. Isto é, para 8.570.524 de homens analfabetos, havia 10.311 .962 mulheres nessa situação. No mesmo ano, a quantidade de matrículas nas duas etapas do curso secundário (ginasial e colegial) foi de 311.996 para os homens e 261.768 para as mulheres, e concluíram seus cursos 39.540 homens e 35.832 mulheres no ano letivo anterior (Saffioti, 2013). Dados como esses indicam enormes dificuldades não apenas quanto ao acesso à escolarização, mas também à permanência e à conclusão de estudos escolares, o que nos leva a indagar quais seriam as barreiras adicionais interpostas às mulheres no seu esforço de profissionalização e/ou de escolarização com vistas à superação de papéis tradicionalmente destinados a elas.

Segundo Saffioti (2013), a transição de escolas masculinas para escolas de coeducação não se fez sem obstáculos nem sobressaltos. Vale lembrar que os primeiros prédios que alojaram escolas de artífices, criadas em cada capital brasileira em 1909, herdaram estruturas de orfanatos que, a exemplo do Colégio das Fábricas (1809), das Casas de Educandos Artífices (1840) e dos Asilos dos Meninos Desvalidos (1854), foram concebidos para funcionar como internato de meninos. À medida que esses espaços foram desarticulando formação e moradia, internação e profissionalização, a convivência entre os sexos foi tornando-se mais viável, embora culturalmente incomum.

Em Brasil (2009), percebemos a pouca presença feminina em fotografias nas escolas de ensino industrial. Quando muito, aparecem nas fotografias figurando como ajudantes, cozinheiras e professoras das unidades de ensino, ou mesmo cônjuges que acompanham docentes e gestores homens em momentos comemorativos. Apenas na década de 1950, conforme Figura 1, as fotos retratam mulheres nos espaços de oficinas. Nessa primeira imagem, pouco comum, podemos observar a presença feminina e negra na escola técnica de Salvador, Bahia, no ensino técnico industrial. Consideramos que a presença negra era muito comum na rede federal antes de as escolas industriais assumirem o status de escolas técnicas federais e passarem a ofertar o ensino de segundo grau profissionalizante de alta qualidade, espécie de passaporte para o ensino superior, quando passou a ser alvo da cobiça das elites.

Sobre a Figura 1, trata-se de um registro instantâneo no qual o fotógrafo se localiza à esquerda das educandas, que, com trajes femininos limpos e vestimenta e 


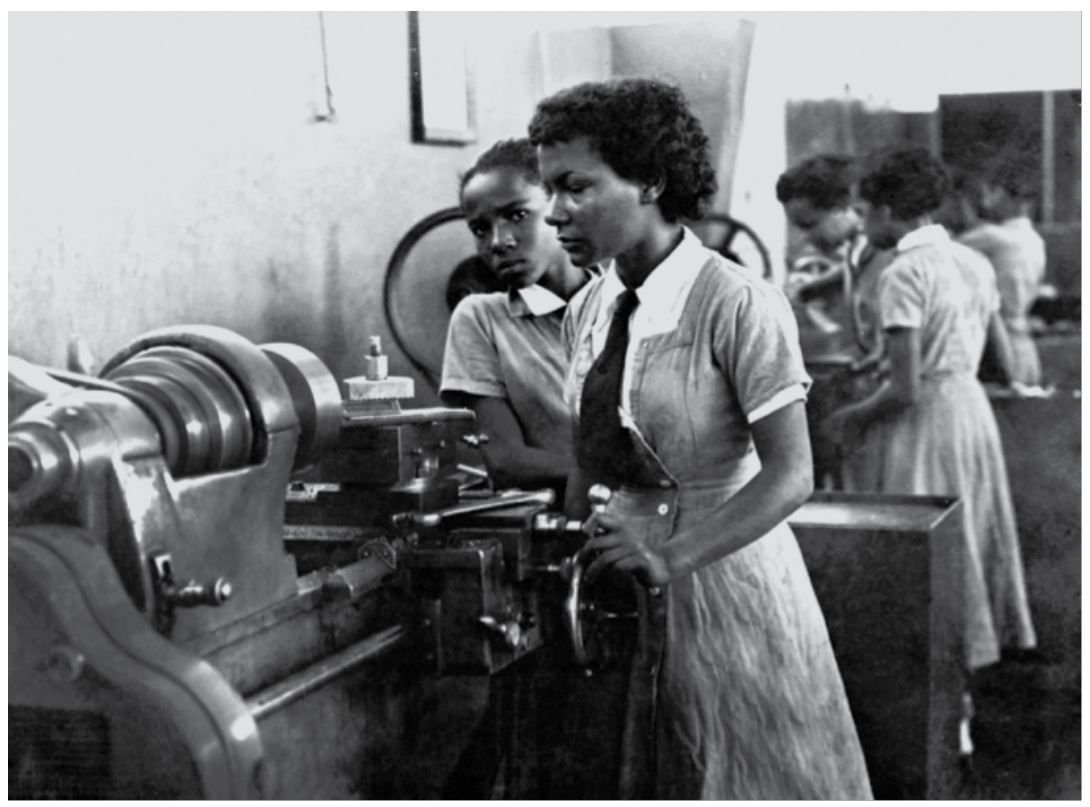

Figura 1 - Década de 1950. Oficina mecânica da Escola Técnica de Salvador, Bahia. Autor desconhecido. Fonte: Brasil (2009).

cabelos arrumados, se situam em frente a um torno mecânico e simulam realizar a atividade de usinagem. Analiticamente, diante de outras fontes da coleção do centenário da rede federal, dialogando com a intertextualidade (Mauad, 2008), podemos presumir a relativa factualidade da presença feminina naquele espaço-tempo. Tal imagem também deve ser vista como mediação (Ciavatta, 2004) de um processo histórico-social que nos ajuda a indagar e, se possível, entender aspectos do processo de inserção de mulheres, pobres e negras naquela instituição de ensino profissional.

Imagens de alunas nessa rede entre aquelas reunidas por Brasil (2009) e Sousa (2019) serão muito mais evidentes da década de 1970 em diante, quando elas aparecem nos espaços dos laboratórios e das oficinas. Embora as leis já permitissem sua presença e os dados informados corroboram matrículas e até formaturas, as fotografias das instituições remetem a um passado recente bastante masculinizado. Nesse caso, na trilha de Benjamin (1987), podemos afirmar que as educandas já se apresentavam, mas não eram sistematicamente retratadas em atividades de aprendizagem industrial.

$\mathrm{Na}$ Figura 1, percebem-se alunas operando máquinas na oficina mecânica. Pela presença das máquinas, podemos identificar que o espaço físico retratado é uma oficina mecânica, e alunos atuam em dupla em cada máquina. $\mathrm{Na}$ imagem, as alunas estão com uniformes, vestidos abaixo dos joelhos, com duas fileiras de botões, por baixo camisas brancas de mangas curtas e gravata escura. Elas olham atentamente para as pesadas máquinas com as quais interagem.

Pouco comum era a presença das mulheres nesses espaços. Retratada de maneira rara, na Figura 1, a presença feminina, apesar de autorizada pela legislação 
desde a década de 1940, em 1950 não estava totalmente garantida. Segundo a lei orgânica do ensino industrial presente no Decreto-Lei no 4.073, de 30 de janeiro de 1942, em seu artigo 5\%, "o direito de ingressar nos cursos industriais é igual para homens e mulheres. A estas, porém, não se permitirá, nos estabelecimentos de ensino industrial, trabalho que sob o ponto de vista da saúde, não lhes seja adequado" (Brasil, 1942).

Antes mesmo da transformação das escolas técnicas em autarquias e sua institucionalização em escolas técnicas federais e da organização curricular das escolas de ensino técnico e industrial, as práticas educativas faziam distinção entre homens e mulheres. Para os alunos, seria dada a educação pré-militar, conforme o artigo 26, parágrafo $1^{\circ}$, do Decreto-Lei $n^{\circ} 4.073$ - e para as alunas, educação doméstica com "misteres próprios da administração do lar" (Brasil, 1942), de acordo com o artigo 26 , parágrafo $2^{\circ}$, do referido decreto-lei.

\section{DA ESCOLA DE APRENDIZES ARTÍFICES AO CENTRO FEDERAL DE EDUCAÇÃO TECNOLÓGICA: APONTAMENTOS SOBRE A EDUCAÇÃO PROFISSIONAL NO ESPÍRITO SANTO (1910-1990)}

Entre as funções e possibilidades do historiador (Bloch, 2001), evidencia-se a reconstrução (ou identificação) de uma delimitação espaçotemporal alicerçada no uso e, sobretudo, na interlocução de variados tipos de fonte. No caso em tela, estruturamos uma investigação sobre o fenômeno tendo em vista a busca pelos vestígios da história local, metodologicamente orientada por recursos presentes na micro-história.

Em nosso recorte investigativo, além da definição temporal, elegemos como lócus uma instituição federal de ensino profissional hoje denominada de IFES. Com base em documentos que detalham sua trajetória, da sua criação, em 1910, até os anos de 1970, buscamos a historicidade do fenômeno em estudo.

Inicialmente denominada de Escola de Aprendizes Artífices do Espírito Santo, a instituição foi inaugurada em 24 de fevereiro de 1910, localizada no centro de Vitória, à Rua Presidente Pedreira, n. $13^{3}$ (Sueth et al., 2009). Nessa fase, funcionou em regime de internato, obedecendo a um projeto pedagógico do tipo primário-profissional e correcional-assistencialista, voltado para o público-alvo de crianças com idades entre 10 e 12 anos. Posteriormente, em 11 de dezembro de 1942, foi denominada de ETV, transferida para o bairro de Jucutuquara (Avenida Vitória), com regime de internato e semi-internato, e orientou-se por um projeto educativo ginásio-profissional do tipo taylorista-fordista, voltado para atender jovens de 13 a 15 anos.

A boa organização do acervo no setor de registros escolares e no centro de memória, setor integrante da Biblioteca Nilo Peçanha, do campus Vitória, permite percorrer muitos aspectos da história da instituição em quase todo o período de 1910

3 Com a Lei no 378/1937, a Escola de Aprendizes Artífices do Espírito Santo passou a ser denominada de Liceu Industrial de Vitória, denominação que durou apenas sete anos. Em 1942, transformou-se em ETV, mesmo sem oferecer cursos técnicos. 
a 1998, quando esta se transformou em Centro Federal de Educação Tecnológica do Espírito Santo (Cefetes). Nesse acervo, ainda que existam lacunas, o conjunto documental é rico e detalhado. Entre as fontes primárias, destacamos:

- atas de matrícula de 1910 a 1934 (manuscritos);

- atas de avaliação de 1911 a 1934 (manuscritos);

- folhas de pagamento de 1914 a 1917 (manuscritos);

- listas de alunos de 1910 a 1934 (manuscritos e datilografados);

- convites para formatura dos cursos de 1942 a 1970;

- fichas individuais dos alunos de 1942 a 1994 (datilografados e em rolos de microfilme);

- fotografias esparsas do período de 1910 a 1998;

- jornais escolares O Eteviano, Gitec e ETFES, de 1949 a 1980.

Diversos trabalhos historiográficos organizaram e analisaram essas e outras fontes para contar os elementos documentais da história da instituição, dos quais destacamos:

- O visgo eteviano, organizado por Joaquim Bothéquia (1979);

- 100 anos dos jovens titãs, organizado por Sueth et al. (2009);

- a dissertação de mestrado profissional A memória da educação profissional e tecnológica no IFES: caminhos para acesso e difusão das fontes documentais no campus Vitória, de Janda T. de Sousa (2019);

- A tese de doutorado Educação matemática e formação para o trabalho: práticas escolares na Escola Técnica de Vitória - 1960 a 1990, de Antônio Henrique Pinto (2006);

- a tese de doutorado Interdiçóes e resistências: os difíceis percursos da escolarização das mulheres na EPT, de Maria José Resende Ferreira (2017).

\section{O INÍCIO DA ESCOLA DE APRENDIZES ARTÍFICES NO ESPÍRITO SANTO (1910-1940)}

Para provar o fenômeno em estudo, tomamos editais de seleção de alunos e listas de matriculados do acervo de memória da instituição referentes ao período de 1910 até a década de 1930. Segundo Sueth et al. (2009), um mês antes da inauguração da escola, em janeiro de 1910, fora doado pelo governador do estado Jerônimo de Souza Monteiro o prédio que seria a primeira sede da Escola de Aprendizes Artífices do Espírito Santo (EAAES) e nomeado para sua direção José Francisco Monjardim. De imediato, segundo Sueth et al. (2009), fora publicado na página 42 do jornal Diário da Manhã de 27 de janeiro de 1910 o que seria o primeiro edital de convocação para matrícula na instituição de ensino:

Acham-se abertas, desde o dia 15 de fevereiro, as matrículas para os cursos nocturnos primário e de desenho e bem assim para aprendizagem nas officinas de marcenaria e carpintaria, alfaiataria, de ferreiro e fundição e eletricidade, sendo gratuitos os referidos cursos e custeados pelo governo federal (ministério da agricultura, comércio e indústria). Conforme dispõe [...] o decreto no 7763 de 23 de dezembro do ano próximo passado, serão admitidos os menores, cujos paes, tutores ou responsáveis o requerem dentro do prazo [...] para a matrícula e 
que possuírem os seguintes requisitos, preferidos os desfavorecidos da fortuna: idade mínima de 10 anos; idade máxima 13 anos; não sofrerem de moléstia infecto-contagiosa; não terem defeitos fhysicos que os inabilitem para aprendizagem do offício. A cada um alumno será apenas facultada a aprendizagem de um só offício consultada a respectiva aptidão e inclinação. (Diário da Manhã, 1910 apud Sueth et al., 2009)

Pelo documento, percebe-se que a procura pela matrícula não era intensa, haja vista a reiteração do anúncio chamando os possíveis educandos, mas, sendo as famílias de baixa renda e provavelmente de baixa escolaridade o público-alvo desse edital, teria sido restrito o acesso à leitura dos jornais por parte dele. Do ponto de vista da questão da presença de mulheres, não fica explícita no texto a exclusão das meninas, como é clara a exclusão das pessoas com deficiência, porém o uso de "a cada um alumno", "ferreiro" e "desfavorecidos", não flexionados no feminino, se por um lado não exclui as meninas, por outro tampouco evidencia que seriam elas parte do público-alvo.

Para avançar na busca pela eventual presença feminina, pesquisamos nos documentos manuscritos (atas da EAAES e lista de pagamentos do Ministério da Agricultura, Indústria e Comércio) algum indício sobre o sexo dos educandos. Observando a Figura 2, temos a imagem de um fragmento de uma página com dados

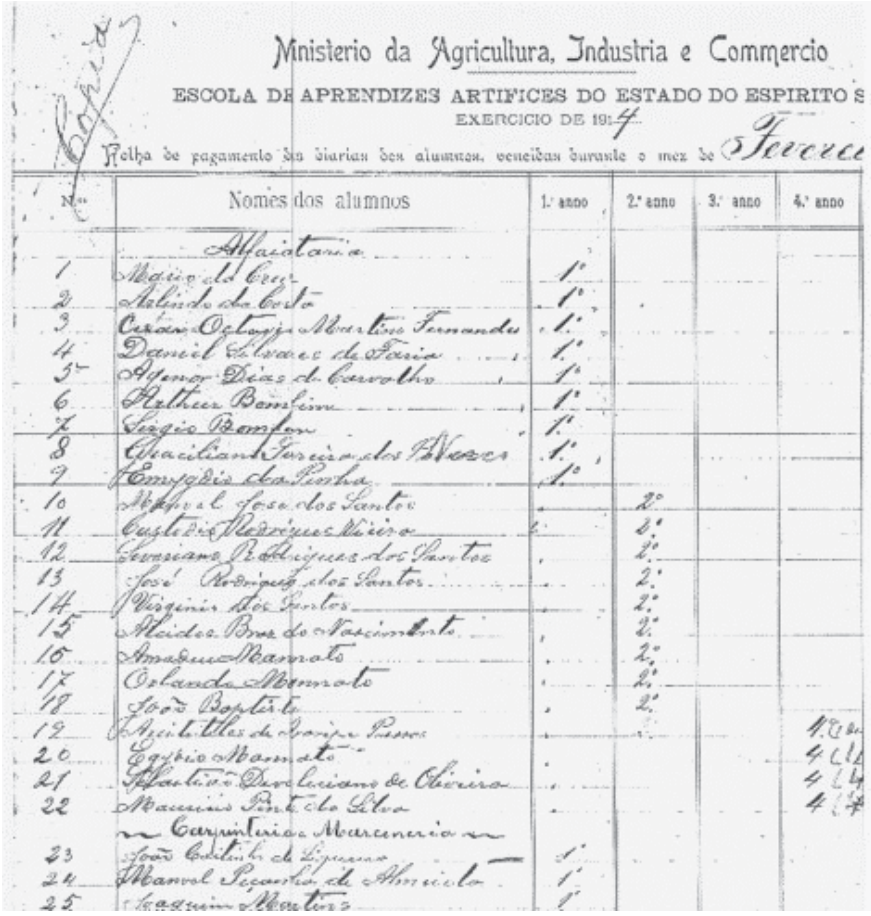

Figura 2 - Folha de pagamento dos alunos do curso de Alfaiataria da Escola de Aprendizes Artífices do Espírito Santo, fevereiro de 1914.

Fonte: acervo da sala de memória do Instituto Federal do Espírito Santo, campus Vitória. 
da remuneração dos alunos em fevereiro de 1914 e uma lista de nomes dos alunos matriculados nos $1^{\circ}, 2^{\circ}$ e $4^{\circ}$ anos do curso de alfaiataria. Esse fragmento pode indicar que a baixa procura obrigou o governo federal a remunerar a frequência à escola.

Entretanto, com base no levantamento das fontes presentes no acervo, há uma lista mais completa, organizada em ordem alfabética, com os primeiros 80 alunos matriculados nos horários diurno e noturno na EAAES no período de 1910 a 1911.

Abel de Almeida/ Admião Macedo/ Agenor José dos Santos/ Alberico Bittencourt/ Alberto de Freitas Guimarães/ Alício Francisco Alves/ Álvaro Gonçalves Ferreira/ Amâncio Paiva/ Antenor Rezende/ Antônio Ávila Junior/ Antônio da Rocha Tagamo/ Antônio dos Anjos/ Argeu Pereira/ Aristóteles Passos/ Ascendino Ferreira Lemos/ Ascendino Leal/ Basílio Ferreira dos Passos/ Benedicto Bahia/ Benedicto Olívio/ Benício Pereira/ Bernardo Clemente Gonçalves/ Bráulio Santa Clara/ Dario de Almeida Vidigal/ Dario Vidigal/ Demétrio Evangelista de Andrade/ Egydio Mannato/ Eugênio Bizzi/ Eugênio Campos Telles/ Eustoigenes Calmon Costa/ Evaristo Martins/ Fernandino Martins da Victória/ Firmino Rangel Álvaro Gonçalves/ Francisco Pedro Neves Xavier/ Heynozolino de Alcântara Soares/ Jaime Ribeiro da Silva/ Jancintho Landim de Menezes/ Jerônimo Gonçalves Felix/ João Bahia/ João Baptista do Nascimento/ João Justiniano da Fraga Santos/ João Justiniano Pinto da Fraga/ João Manhães/João Pereira Porto/ João Ribeiro da Silva/ João Ribeiro da Victória/ Joaquim Pereira da Silva/ José Carlos da Andrade/ José da Rosa Ribeiro/ José Romancinno do Nascimento/ Lazaro Borges/Leocádio dos Passos Salles/ Leocondino Cruz/ Lúcio de Oliveira/ Luis Moreira de Carvalho/ Luis Paiva/ Luis Passos/ Lydio Martins Flores/ Manoel Genésio/ Manoel José dos Santos/ Manoel Moraes da Victória/ Manuel dos Passos/ Maurício Pinto da Silva/ Miguel do Nascimento/ Olindo Cassilhos/ Olintho Faria dos Santos/ Olívio Camponez/ Onelatino Borges Caldeira/ Oscar Aniceto do Prado/ Osvaldo dos Santos/ Palmerino Motta/ Paulino dos Santos/ Pedro Patrocínio/ Plínio Miguel do Nascimento/ Sebastião Deocleciano de Oliveira/ Silvio Barreto Bacio/ Themis Landim de Menezes/ Umberto Mannato/ Urbano Salgueiro Filho/ Vasco da Silveira/ Vicente Balbi/ Virgínio dos Santos. (Lima, 2010, p. 6)

Sem a imagem do grupo e analisando apenas a lista, tentamos por meio das características dos nomes eventualmente associá-los ou não ao sexo feminino. Observando a listagem, apenas alguns poucos indícios podem ser sinalizados. Somente um nome poderia ser feminino, Themis, mas esse dado não garante nenhuma certeza. Todavia, em termos metodológicos, como ensina Ginzburg (1989), pode ser um vestígio importante.

Não obstante, para avançar na identificação do início da presença feminina na instituição criada no começo do século passado, fase em que poucos espaços eram destinados à formação e/ou escolarização das mulheres, analisamos fontes escritas e também imagéticas, no sentido de evidenciar a presença feminina nesses espaços de formação. Ao longo da pesquisa, cruzamos essa informação com outras disponíveis no acervo do IFES. 
A tentativa primeira foi de, por meio das imagens, averiguar essa questão, pois a presença de mulheres nas fotografias nos daria indícios para revelar o fenômeno em tela, porém, à luz de Kossoy (2000), Ciavatta (2004) e Mauad (2008), retomamos o fundamento segundo o qual as fotografias não retratam de forma absoluta os fatos históricos, podendo ser também objeto de manipulação tanto na sua produção quanto na sua preservação.

Entretanto, no cruzamento com outros tipos de fonte, o uso de imagens como fonte histórica pode fornecer elementos mais eloquentes de identificação da presença feminina na instituição, além de permitir o debate historiográfico sobre a validade, importância e natureza da pluralidade de fontes de pesquisa histórica. Para tanto, inicialmente, trazemos imagens dos supostos estudantes perfilados (Figuras 3 e 4), que nos permitiram perceber e/ou avaliar a presença, a ausência e/ ou o apagamento/a exclusão das mulheres na EAAES.

Longe de tentar obter ou produzir uma historiografia definitiva ou inquestionável, as fotografias, assim como os documentos em geral, precisam ser lidas com cuidado, tomadas como monumentos destinados a produzir uma memória que se combina muitas das vezes com o apagamento de outras fontes. Sabemos que sociedades e instituições produzem e/ou preservam documentos com muitas intencionalidades, até mesmo a de gerar uma narrativa histórica ideologicamente

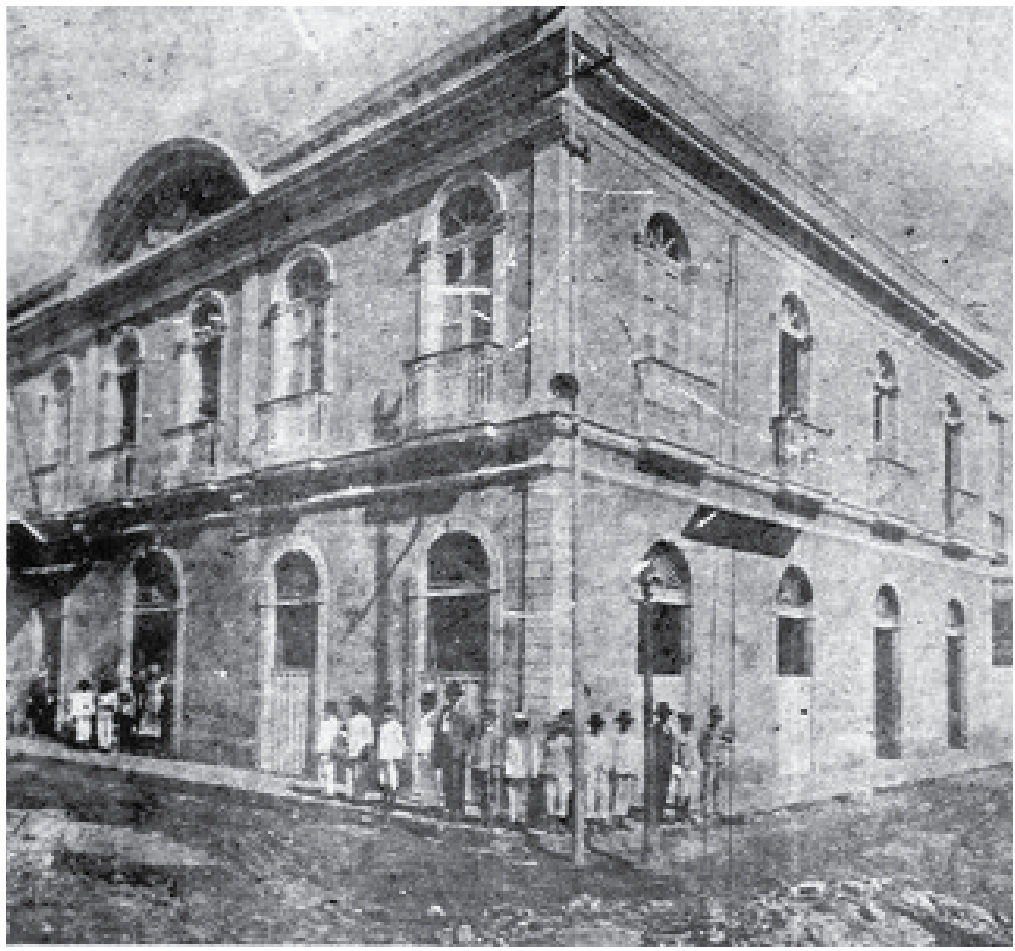

Figura 3 - Escola de Aprendizes Artífices no Espírito Santo (1910-1917), inaugurada em 24 de fevereiro de 1910, à Rua Presidente Pedreira, n. 13, centro de Vitória, Espírito Santo.

Fonte: Brasil (2009). 


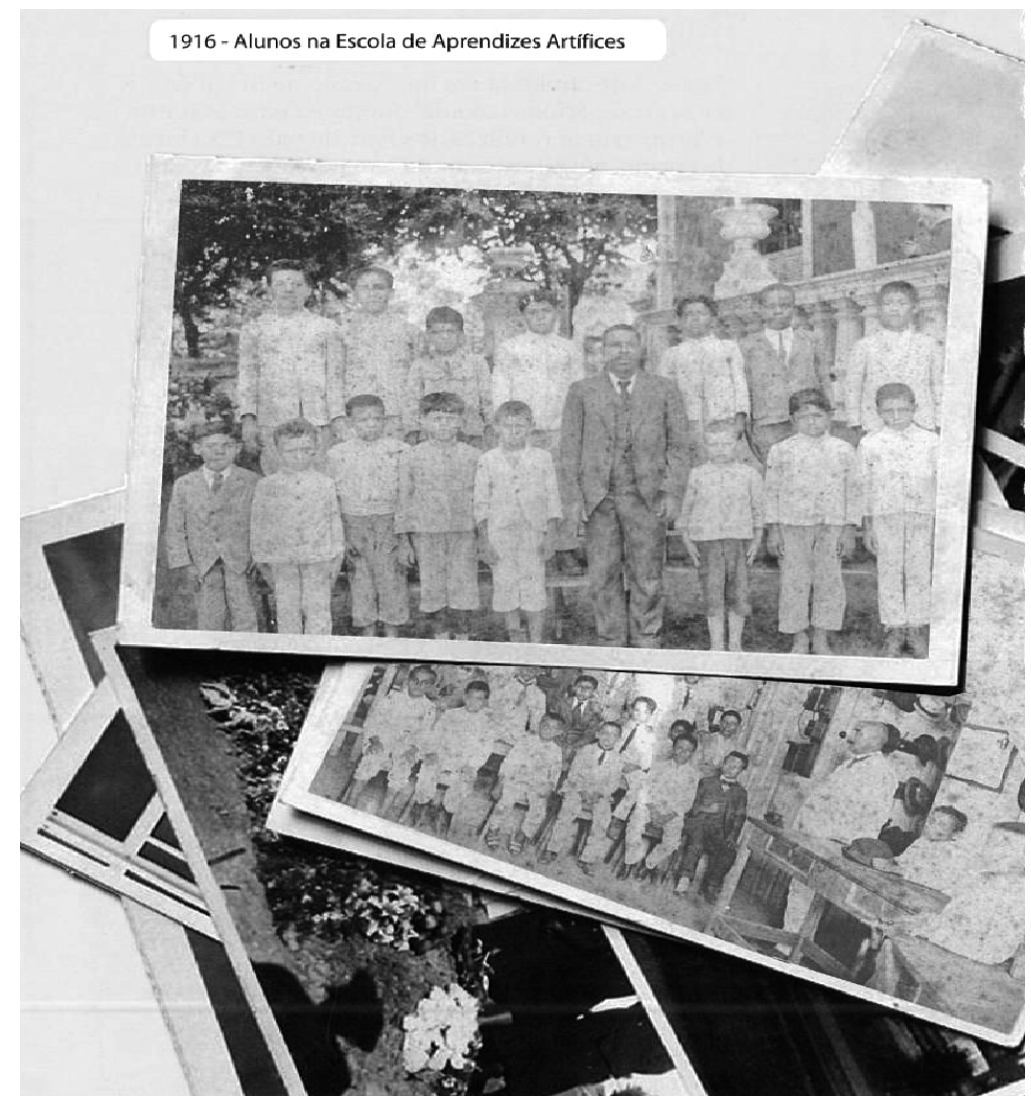

Figura 4 - Turmas de 1916 da Escola de Aprendizes Artífices no Espírito Santo, centro de Vitória, Espírito Santo. Autores desconhecidos.

Fonte: acervo da sala de memória do Instituto Federal do Espírito Santo, campus Vitória, e agenda IFES 2009.

determinada (Le Goff, 1996; Pinsky e Luca, 2009). Ou seja, no processo de produção e de preservação das imagens, apagam-se umas e reiteram-se outras informações por motivos e intencionalidades específicos. Assim, também as fotografias estão longe de serem isentas de ideologias e de serem usadas em âmbitos político e institucional. Muitas vezes as imagens mostram, mas também ocultam. Aqui podemos perceber nas Figuras 3 e 4, tiradas provavelmente entre 1910 e 1916 (documento comemorativo à época do centenário da rede federal do Cefetes, 2009), que os aprendizes estão colocados em posição de pose.

Pela análise realizada, acreditamos que houve construção da cena, uma vez que os alunos menores de idade (crianças e adolescentes), perfilados, foram possivelmente vestidos e organizados para serem fotografados em situação de pose. Trata-se, portanto, de imagens não espontâneas, nas quais se observa ausência total de pessoas do sexo feminino (como professoras ou alunas). Assumindo o viés indiciário de Ginzburg (1989), problematizamos a cena; não sabemos se meninas teriam sido retiradas da cena ou se de fato não faziam parte do corpo discente ou docente. 
Para tentar elucidar essa questão, fazemos a análise cruzada das fotografias entre si (como orienta Mauad, 2008) e entre elas e outros tipos de documentos (como orientam Pinsky e Luca, 2009). Ou seja, na interlocução entre as fontes escritas na sua relação com o que nos revelam (ou o que escondem, como orienta Benjamin, 1987), as imagens, ao serem intercruzadas, ajudam-nos a compreender as fontes não apenas no que elas trazem individualmente, mas no seu conjunto. Assim, com base nas listagens disponíveis no acervo, tentamos definir uma posição historiográfica sobre a composição do sexo do corpo discente no espaço-tempo em tela. Inicialmente, tendo em vista a análise do contexto nacional da legislação e das fontes disponíveis no espaço local, na cronologia dos anos de 1910 até os de 1930, podemos concluir que provavelmente não havia mulheres na instituição.

\section{ESCOLA TÉCNICA DE VITÓRIA (1940-1965): A PRESENÇA FEMININA ESQUECIDA} PELA MEMÓRIA OFICIAL

Prosseguindo com a análise da década de 1940, ano em que a instituição, instalada em novo prédio, foi transformada em ETV, percebemos mudanças nos tipos de curso ofertados, bem como nas idades dos educandos, quando se passou a ministrar os cursos industriais básicos (Tipografia e Encadernação, Artes em Couro, Marcenaria, Alfaiataria, Mecânico de Máquinas, Pintura e Serralheria). Segundo Sueth et al. (2009), o grupo da Figura 5 constituiu a primeira turma formada, em 1946, na ETV na nova sede, em Jucutuquara, inaugurada em 1942. Conforme os autores, nessa imagem estão presentes os alunos Loadir Carlos Pasolini e Admercil Silva, que viriam a se tornar funcionários da escola. Também figura Jair Marino, autor do hino da instituição.

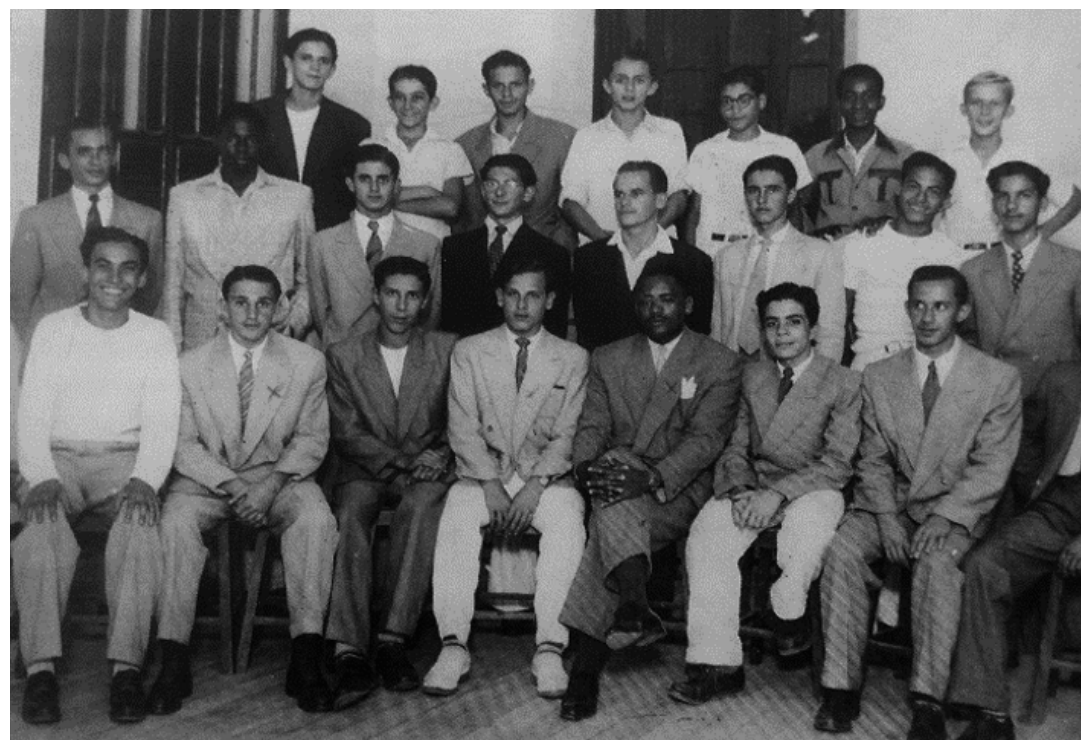

Figura 5 - Primeira turma formada, em 1946, na Escola Técnica de Vitória, nova sede em Jucutuquara, Vitória, Espírito Santo. Autor desconhecido.

Fonte: Sueth et al. (2009). 
Considerando diferentes fontes ao longo da pesquisa, deparamos com os convites de formatura disponíveis na sala de memória (Figuras 6 e 7), acervo do IFES, campus Vitória. Neles foi possível evidenciar indícios da presença feminina na instituição, embora informem apenas os concludentes dos cursos, por se tratar de convites de formatura. De acordo com os documentos, formaram-se, no ano de 1947, os alunos cujos nomes iniciais são Adir, Álvaro, Irani, Jaime, Joceni, Josino e Loadir ${ }^{4}$, em Tipografia e Encadernação; Clóvis, em Artes em Couro; Antônio, Carlos, Jessi e Wilmar, em Marcenaria; José e Lamartine, em Alfaiataria; Antístenes, Ataíde, Constantino, Dalcíades, Delcilio, Edgard, Fabio, João, José, Júlio, Manoel e Paulo, em Mecânico de Máquinas; Abel, Almir e Ilson, em Pintura; e Áureo, Giomar, Gilmir, João e Uilcas, em Serralheria. Desses nomes, Adir, Irani, Joceni,

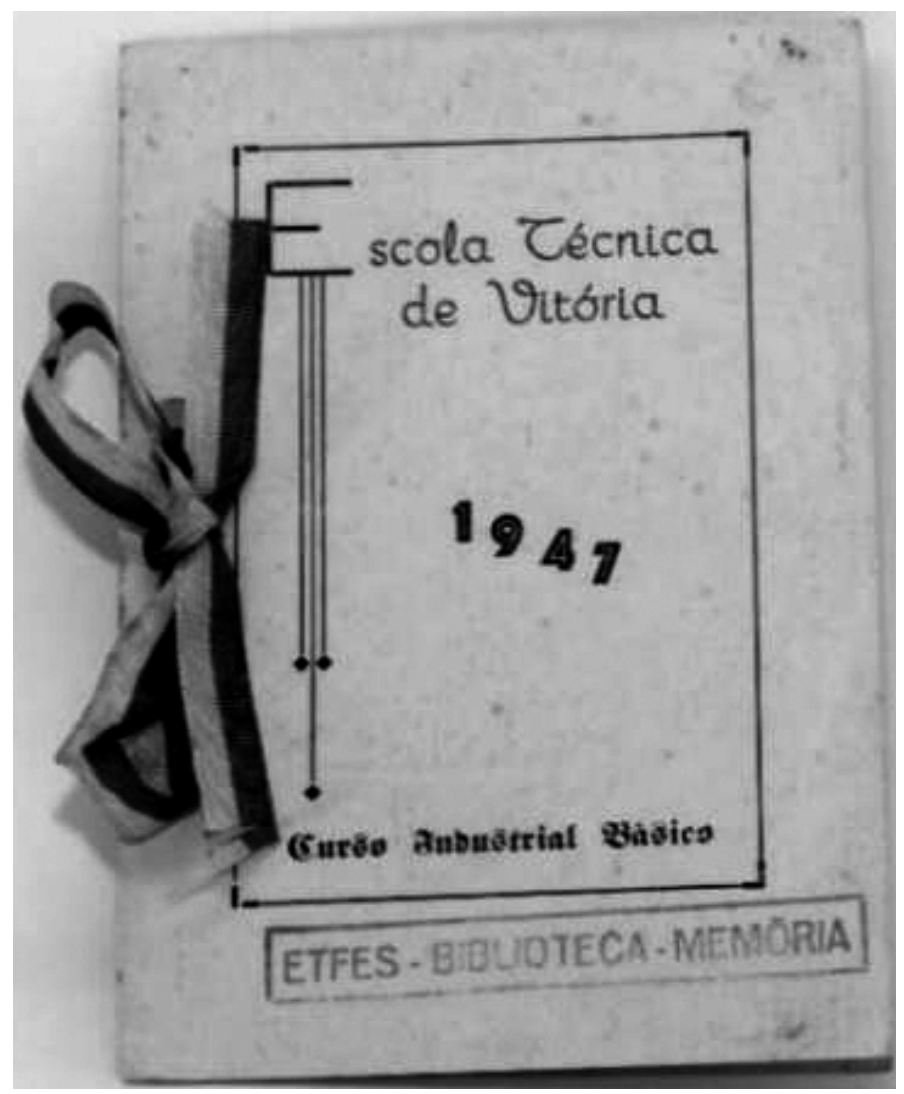

Figura 6 - Capa do convite de concludentes do curso industrial básico da Escola Técnica de Vitória, 1947. Fonte: acervo da sala de memória do Instituto Federal do Espírito Santo, campus Vitória.

4 Loadir Carlos Pasolini, que se tornaria mais tarde funcionário da instituição, consta da fotografia e também figura no convite de 1947. Esse nome, porém, está riscado a lápis no convite, deixando dúvidas sobre sua presença na formatura de 1946 ou 1947. Esse caso é interessante para mostrar como duas fontes diferentes podem dar detalhes distintos e, às vezes, divergentes, cabendo maior aprofundamento histórico. 


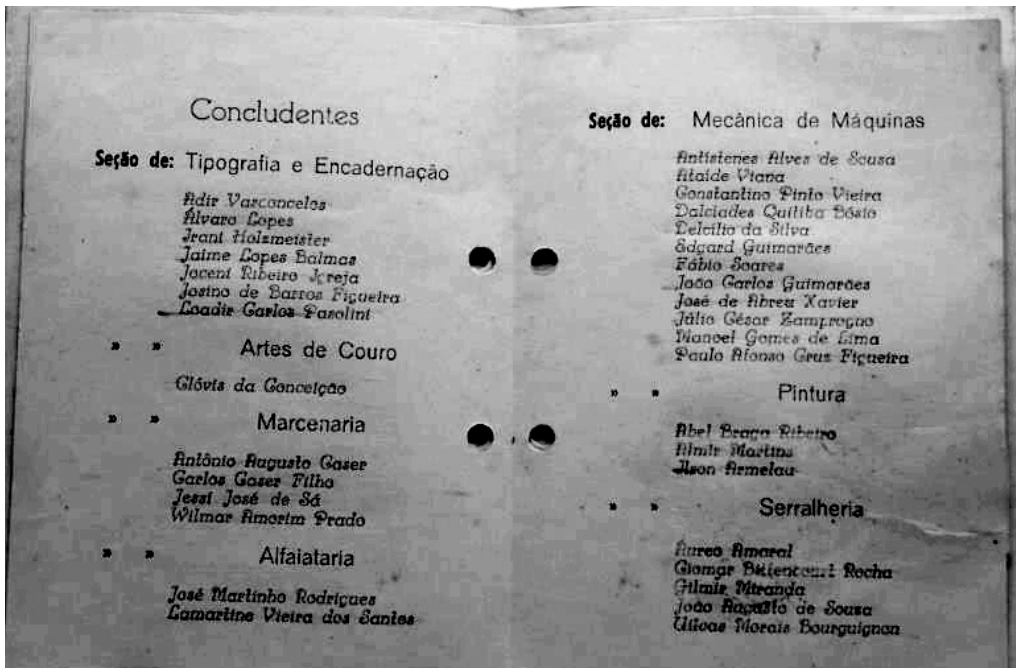

Figura 7 - Página 4 do convite de concludentes do curso industrial básico da Escola Técnica de Vitória, 1947. Fonte: acervo da sala de memória do Instituto Federal do Espírito Santo, campus Vitória.

Loadir, Jessi, Dalcíades, Giomar e Uilcas são nomes que poderiam ser de pessoas do sexo feminino, o que não deixa claro se havia ou não mulheres nesses cursos.

Todavia, no documento de 1953 (Figura 8) - o convite com a lista de egressos dos cursos da ETV - a participação feminina fica mais explícita. Dos 25 formandos, entre vários nomes masculinos, aparecem nomes caracteristicamente femininos, como Clemar, Jacir e, sobretudo, Marina, indicativos da presença feminina. Na trilha de Ginzburg (1989) e Le Goff (1996), precisamos relativizar essa fonte, pois se trata do registro de egressos concluintes dos cursos. Ou seja,é possível que determinados alunos ou alunas, matriculados ou matriculadas, tenham feito o curso e, eventualmente, não o tenham concluído. Assim, a essas turmas podem ter tido acesso pessoas que foram excluídas antes da conclusão do curso.
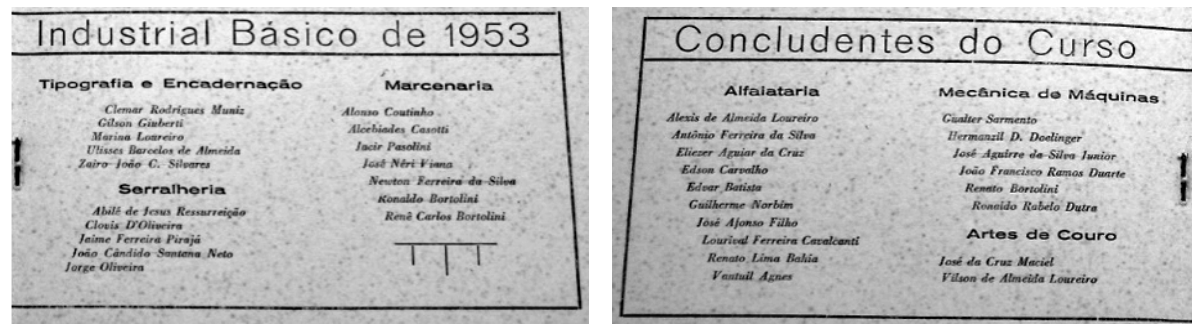

Figura 8 - (A e B) Páginas do convite de concludentes do curso industrial básico da Escola Técnica de Vitória, 1953. Fonte: acervo da sala de memória do Instituto Federal do Espírito Santo, campus Vitória.

Com base na documentação disponível no acervo, observa-se, no Quadro 1, uma lista de alunas que fizeram, entre 1950 e 1964, o curso industrial básico na ETV para as ocupações de Tipografia e Encadernação e Alfaiataria. No Quadro 1, 


\section{Quadro 1 - Primeiras educandas matriculadas nos cursos da Escola Técnica de Vitória, 1950-1960.}

\begin{tabular}{|l|c|c|c|}
\hline Nome & Curso & Entrada & Saída \\
\hline Marina Loureiro & Tipografia e Encadernação & 1950 & 1953 \\
\hline Gilda Toscano Brito & Tipografia e Encadernação & 1950 & 1954 \\
\hline Zilda Trindade & Tipografia e Encadernação & 1950 & 1951 \\
\hline Dalva Silveira Pinto & Tipografia e Encadernação & 1950 & 1951 \\
\hline Dulce Ferro & Tipografia e Encadernação & 1950 & 1950 \\
\hline Anizia Luiza Espírito Santo & Tipografia e Encadernação & 1950 & 1952 \\
\hline Janedir Glória Nascimento & Tipografia e Encadernação & 1950 & 1954 \\
\hline Ana Rita Gomes Augusto & Tipografia e Encadernação & 1950 & 1950 \\
\hline Maria Imaculada Soares & Tipografia e Encadernação & 1951 & 1951 \\
\hline Jaila Borges & Alfaiataria & 1951 & 1952 \\
\hline Maria da Glória Marculano & Tipografia e Encadernação & 1952 & 1955 \\
\hline Nair Varejão Pádua & Alfaiataria & 1952 & 1952 \\
\hline Vanda Maria Lucas & Alfaiataria & 1952 & 1953 \\
\hline Telma Alves Paiva & Tipografia e Encadernação & 1957 & 1960 \\
\hline
\end{tabular}

Fonte: acervo com as listas de matriculados, convites de formatura e fichas de alunos vinculados ao período de 1950 a 1960.

constatamos que nem todas as pessoas do sexo feminino concluíam os cursos em três anos. Algumas saíram no mesmo ano em que entraram, ou em um, dois ou três anos, enquanto outras levaram quatro anos para terminar a sua formação.

Como afirma Sousa (2019), a legislação nacional a partir de 1940 permitia às mulheres frequentarem a escola de ensino industrial. Contudo, apesar da possibilidade de matrícula, como descrito por Souza (2008), na escola básica no Brasil poucas conseguiam concluir a formação no ensino secundário, em geral, e no ensino industrial, particularmente.

Segundo informações dos documentos de alunos reprovados e de editais de seleção da instituição presentes no acervo, muitos eram os mecanismos de exclusão e de seletividade. Além do exame de seleção e do direcionamento das escolas, que definiam os cursos que as mulheres deveriam e poderiam fazer, em alguns casos de exclusão de alunos (mas sobretudo de alunas) se justificava a retirada da ou do discente por reprovação ou inadaptação ao ofício. Para tanto, utilizava-se a expressão "não revelou pendores para o ofício", registrada na ficha individual dos alunos, no item "boletim de merecimento".

A documentação indica a presença de mulheres na década de 1950, destacando sua vinculação aos cursos de Tipografia e Encadernação, por se tratar de atividade menos braçal e mais leve. Segundo Pinto (2006), esse público vinculava-se mais aos cursos de Alfaiataria, que seria congênere ao curso de Corte e Costura, oficialmente destinado às mulheres e ainda oferecido em algumas escolas técnicas de outros estados.

Em tempos em que mulheres negras, e provavelmente pobres, estudavam na ETV fazendo os cursos em geral de Alfaiataria e Tipografia e Encadernação, a documentação apresentada nas Figuras 9 e 10 revela que a reprovação na sequência em uma das séries significava a exclusão, caso da aluna Ana Rita Gomes Augusto. 


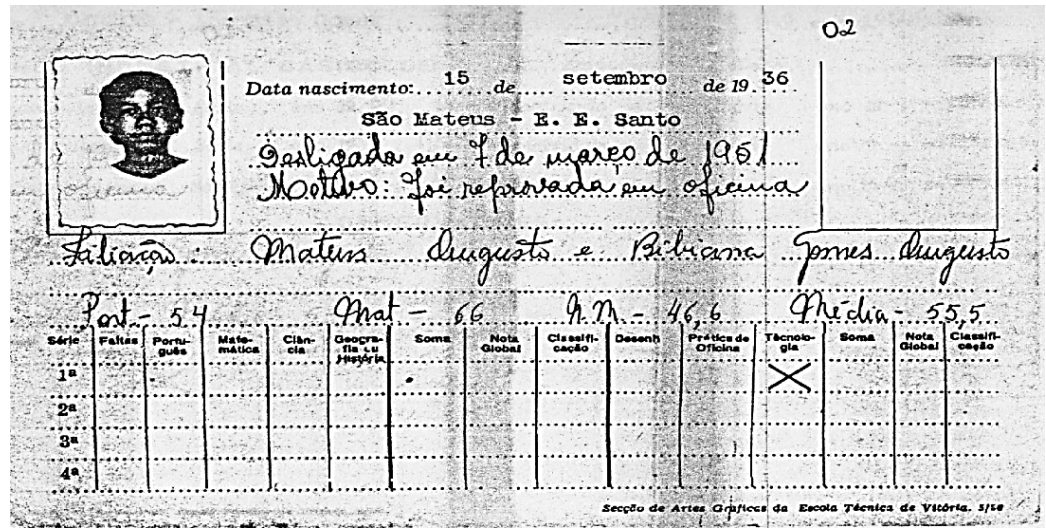

Figura 9 - Página 2 da ficha individual de registro da aluna Ana Rita Gomes Augusto, 1950.

Fonte: acervo de fichas individuais da sala de registros escolares do Instituto Federal do Espírito Santo, campus Vitória.

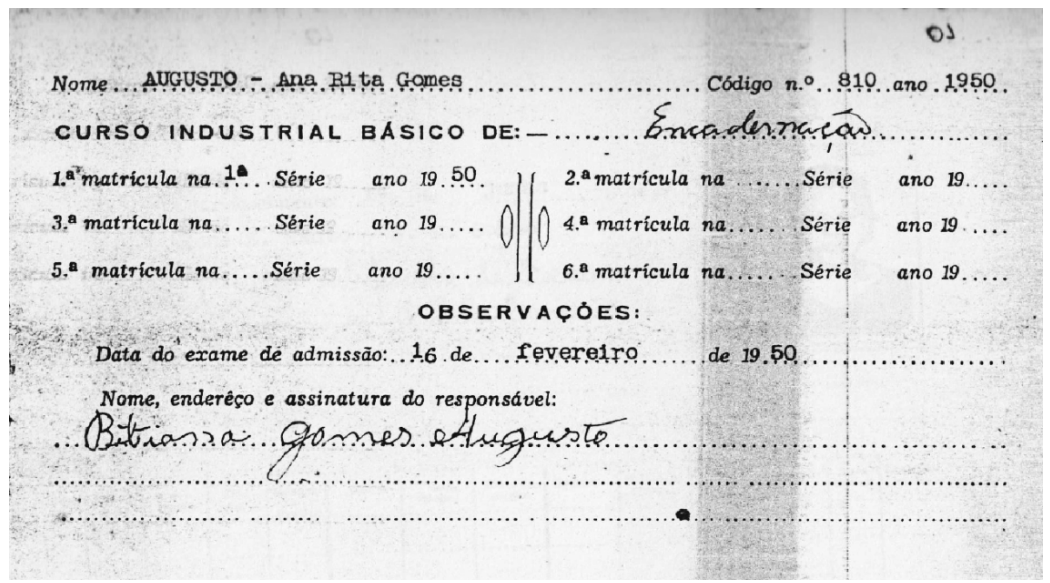

Figura 10 - Página 1 do registro da aluna Ana Rita Gomes Augusto, 1950.

Fonte: acervo de fichas individuais da sala de registros escolares do Instituto Federal do Espírito Santo, campus Vitória.

Embora poucas fotografias coloquem em cena imagens de mulheres entre os educandos dessa instituição, a presença feminina era real, ainda que muitas vezes inviabilizada ou pouco tolerada. Nas Figuras 9 e 10, há uma aluna, filha de Mateus Augusto e Bastiana Gomes Augusto, nascida em 15 de setembro de 1936, que, com 14 anos, fez teste de admissão, em 16 de fevereiro de 1950, obtendo nota 54 em português e 66 em matemática. Ela foi reprovada na oficina, o que lhe rendeu o desligamento da instituição em 7 de março de $1951^{5}$.

5 Em razão do tempo em que ocorreram esses fatos, não foi possível obtermos autorização da aluna para informar tais dados. De qualquer maneira, julgamos que essas informaçõ̃es não desmerecem a pessoa da aluna. Ao contrário, remetem ao papel pioneiro desta na instituição. Apoiamo-nos aqui na legislação decorrente da Ação Direta de Inconstitucionalidade (ADI) 4.815 (apud Tomaz e Porto, 2015), que autoriza a produção de biografias. 
Aqui a instituição parece atribuir aos alunos a responsabilidade pela sua própria aprendizagem. Vale saber se tal procedimento atingiu todos os alunos da mesma maneira ou se as mulheres eram preferidas ou não na reprovação e exclusão. Pelo visto, vem de longe a tradição meritocrática e seletiva da instituição que excluía alunos que não alcançavam a aprovação em qualquer das etapas/dos anos/ das séries dos cursos, o que impediu a permanência da referida aluna. No rastro da problematização das fontes históricas, cabe perguntar se esse procedimento incidia com maior força nas mulheres ou se a exclusão ocorria sistematicamente com os homens também, e se havia maior ou menor incidência dependendo da raça e das condições sociais.

\section{A ESCOLA TÉCNICA FEDERAL DO ESPÍRITO SANTO (1965-1990): QUESTIONAMENTO À MEMÓRIA OFICIAL SOBRE A PRESENÇA FEMININA NA INSTITUIÇÃO}

Depois do período de 1909 a 1942, o ensino industrial, apesar de sua vinculação com o governo federal, não possuía boa estrutura física nem pedagógica, mas esse tipo de instituição elitizou-se e tornou-se, ao longo do tempo, modelo de qualidade de ensino, sobretudo nos anos de 1960. Quando viraram ETFs, evidenciou-se intensa procura pelas elites locais que miravam no ensino superior. As seleções de acesso resultavam, não ocasionalmente, em turmas de alunos compostas em sua maioria de maiores contingentes de homens brancos de classes abastadas.

Depois de terem sido transformadas em autarquias pelo Governo Kubitschek nos anos de 1950, as escolas técnicas converteram-se, já na virada dos anos de 1960-70, em escolas técnicas federais, nos governos militares, e, em pleno milagre brasileiro, tiveram melhoradas ainda mais suas infraestruturas e progressivamente a extinção dos cursos técnico-ginasiais (Industrial Básico, Aprendizagem Industrial e Ginásio Industrial), homogeneizando a oferta escolar totalmente em cursos técnicos de $2^{\circ}$ grau, tendencialmente destinados a um público homogêneo, cada vez mais branco e de classes média ou alta. Desse modo, seguindo a lógica da teoria do capital humano e com o fito de reproduzir a força de trabalho em quantidade e em qualidade requerida pelo capital, os governos militares tiveram de prover de modo diferenciado um tipo de escola pública de ensino profissional. Foram obrigados, assim, a financiar e assegurar a reprodução do trabalho complexo para maior produção de mais-valia relativa aos projetos industriais em andamento.

Do fim dos anos de 1950 ao início da década de 1970, transcorreu uma fase intensa de transformações na instituição. Em 1959, pela Lei no 3.552, as escolas técnicas foram elevadas à condição de autarquia (Sueth et al., 2009, p. 75). Em 1961, extinguiu-se o curso industrial e começou o curso técnico em Estradas. Em 1965, a ETV passou a ser denominada de ETFES, pela Lei no 4.759, portaria do Ministério da Educação de 3 de setembro de 1965 (apud Sueth et al., 2009, p. 77). Encerraram-se as turmas de Aprendizagem Industrial em 1968 e do Ginásio Industrial em 1973.

Pela qualidade, a ETFES, antes denominada ETV, com seu internato e regime escolar militar, ainda vista como escola de pobres, passava a ser procurada por pessoas de todas as etnias, classes e gêneros nos processos de seleção. Nesse 
contexto, depois de uma década sendo sistematicamente excluídas, as meninas brancas, de classe média e egressas do ginásio secundário na década de 1960 ou do ensino de $1^{\circ}$ grau nos anos de 1970 , buscavam a instituição para fazer o $2^{\circ}$ grau profissionalizante em cursos técnicos a elas permitido. O trabalho de Sueth et al. (2009) reitera a presença feminina só a partir dos anos de 1970 e apenas nos cursos técnicos. Esse importante trabalho comemorativo dos 100 anos da instituição, fazendo alusão a uma situação de hasteamento da bandeira, afirma que, em 1972,

pela primeira vez foi escolhida uma professora e não um professor, para proferir saudação a bandeira [...]. Professora Maria Helena Teixeira de Siqueira. Curiosamente, fora esse também o ano em que se criaram condições para o ingresso de mulheres nos cursos técnicos, tendo sido criado banheiros e vestiários para alunas. [...] Também foi neste ano em que os registros assinalaram os primeiros nomes femininos na lista de formandos dos cursos técnicos: Lucineia Gonçalves da Silva e Arlete de Vargas Guimarães (Edificações). (Sueth et al., 2009, p. 111)

Observando a documentação da aluna nas Figuras de 11 a 15, percebemos que a estudante esteve regularmente matriculada e que, na solicitação (Figura 11) encaminhada à diretoria de ensino, a escola se refere à educanda como pioneira. O trabalho de Ferreira (2017) reitera a presença inaugural das mulheres a partir de 1971, quando teria sido regulamentada a abertura de matrícula para mulheres. Segundo a autora, que pesquisou documentos da gestão da época, conforme a ata do conselho de professores: "O Sr. Presidente informa que no próximo ano será livre a escolha para o elemento feminino" (Ferreira, 2017, p. 95).

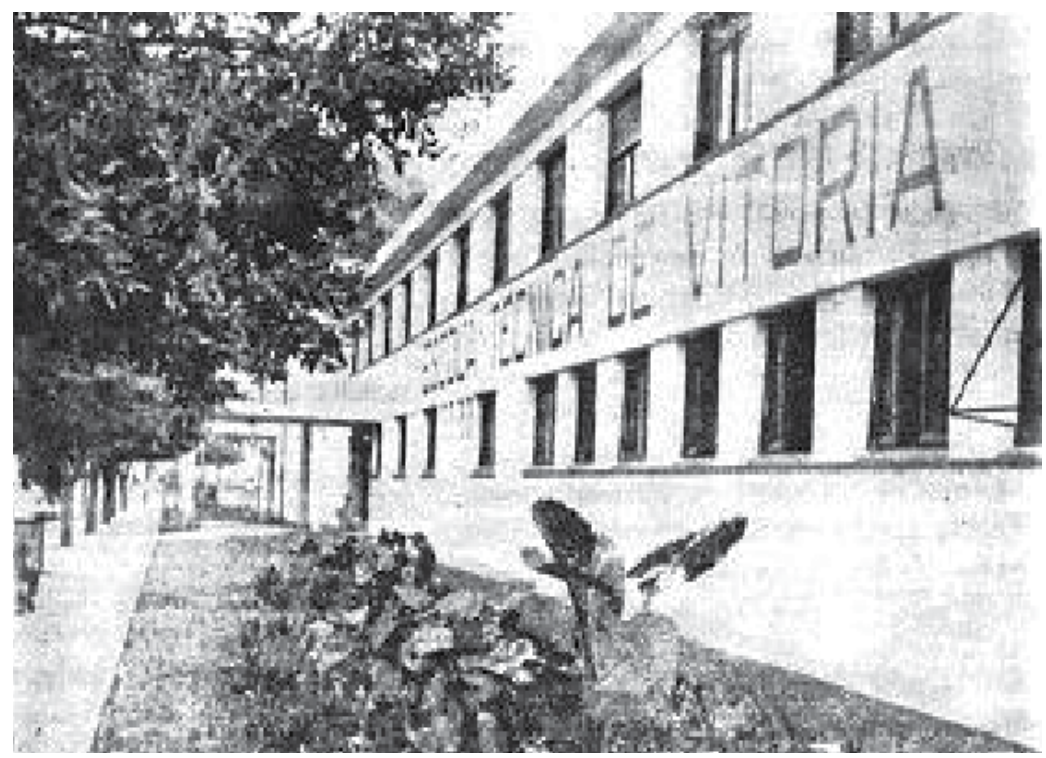

Figura 11 - Escola Técnica de Vitória, inaugurada em 11 de dezembro de 1942, Jucutuquara, Vitória, Espírito Santo (hoje, campus Vitória do Instituto Federal do Espírito Santo).

Fonte: acervo do jornal O Eteviano, da sala de memória do Instituto Federal do Espírito Santo (IFES), campus Vitória. 


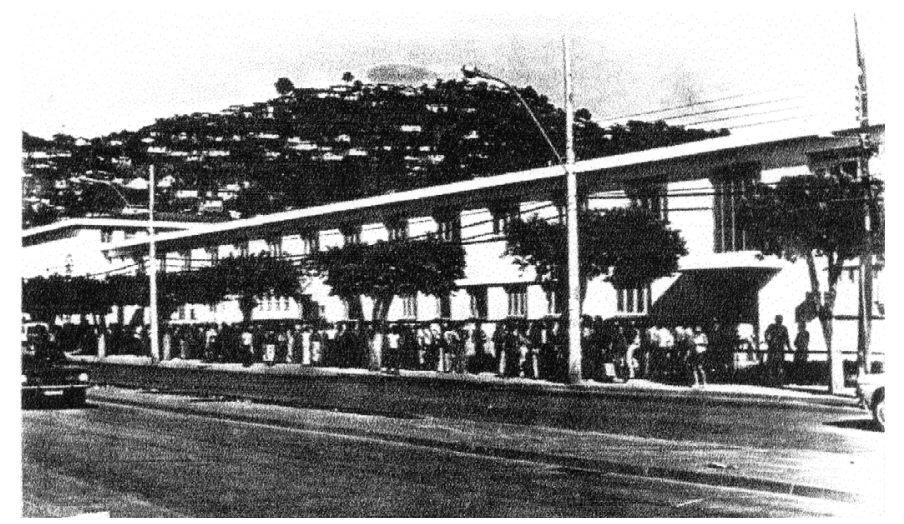

Figura 12 - Escola Técnica Federal do Estado do Espírito Santo, anos de 1980, Jucutuquara, Vitória, Espírito Santo. Fila em frente à escola técnica no dia da seleção. Autor desconhecido.

Fonte: jornal $O$ Gitec, da sala de memória do Instituto Federal do Espírito Santo (IFES), campus Vitória. Acervo fotográfico do IFES, campus Vitória.

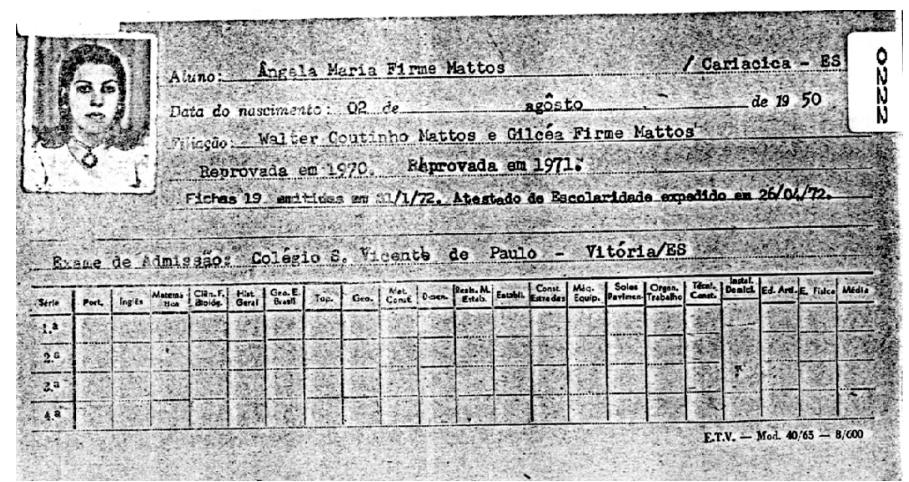

Figura 13 - Página 2 da ficha individual de registro da aluna Ângela Maria Firme Mattos, de 1971.

Fonte: acervo de fichas individuais da sala de registros escolares do Instituto Federal do Espírito Santo, campus Vitória.

Em tom autorizativo e a contragosto, o presidente do conselho de representantes ${ }^{6}$ parece admitir essa obrigatoriedade, afirmando literalmente que não podiam "alterar um dispositivo constitucional" (Ferreira, 2017, p. 95). A imagem de uma organização escolar baseada em valores cívicos e militares era muito associada ao universo do ensino industrial, e nos diversos registros fotográficos do corpo discente enfileirado se ressalta a figura masculina. Esses fundamentos estavam presentes também no projeto pedagógico muito associado ao esforço e ao desempenho, o que pode ser constatado no hino da escola, que viria a ser denominado de "Marcha da ETFES”, de autoria de Jair Marino (formado na primeira turma 1946), com música da professora Maria Penedo (Jornal ETFES, 1979 apud Bothéquia, 1979):

6 "Vale lembrar que esse conselho era uma instância decisória democrática que geria a escola e era responsável pela escolha do diretor. Tanto que em 1974 durante a ditadura civil-militar foi extinto pelo Decreto no 75.079" (Sueth et al., 2009, p. 89). 


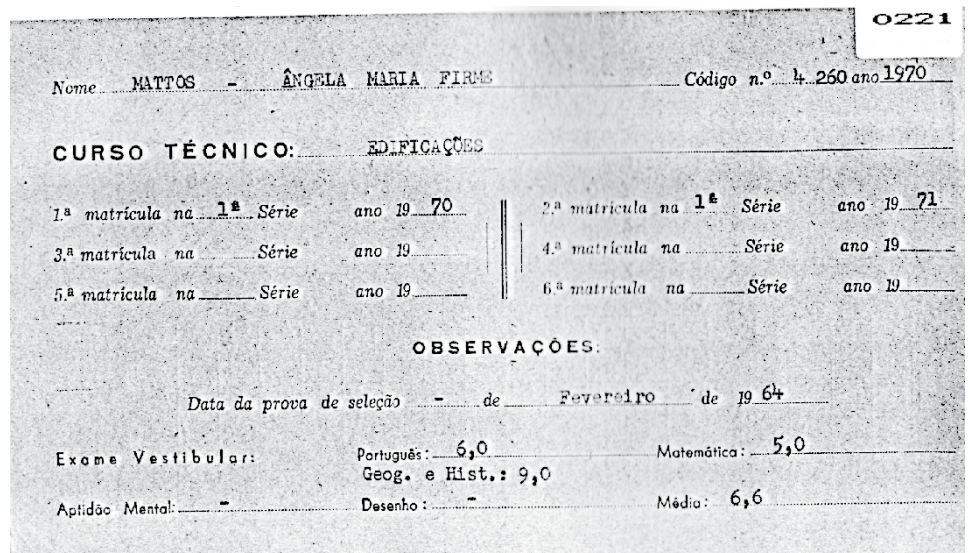

Figura 14 - Página 1 da ficha individual de registro da aluna Ângela Maria Firme Mattos, de 1971.

Fonte: acervo de fichas individuais da sala de registros escolares do Instituto Federal do Espírito Santo, campus Vitória.

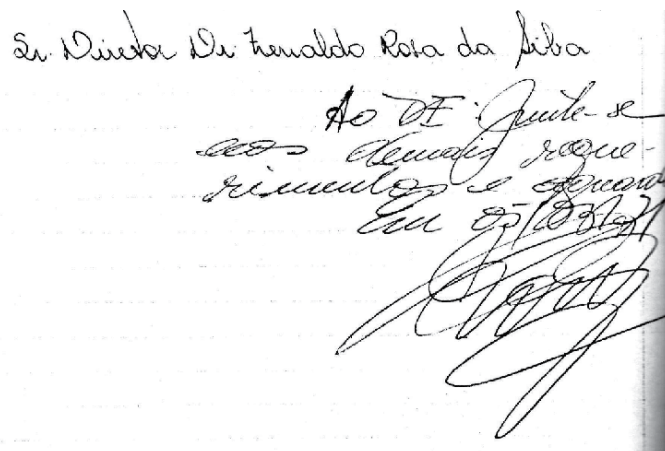

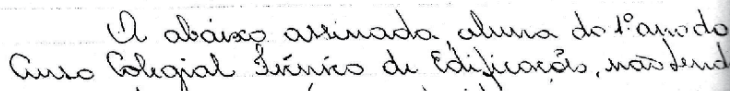

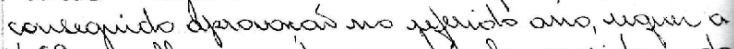
V. So ave lle concida numathuba, considenando que Joi pionina ma Exola e ame be sente busso

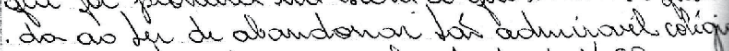

Guntando com a browdonth de V. So Pede dulevimundo.

Vitória, 5 de mano de 1971 Gingela maria firme rujatlos.

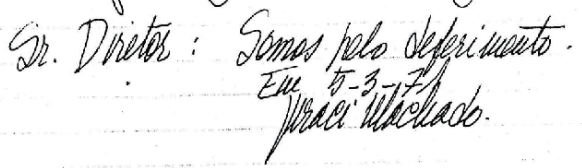

Figura 15 - Requerimento de 5 de março de 1971 de Ângela Maria Firme Mattos para diretor da escola deferido pela diretoria de ensino.

Fonte: acervo de fichas individuais da sala de registros escolares do Instituto Federal do Espírito Santo, campus Vitória. 
Na marcha incessante do progresso,

os corações vibrando de ardor,

Caminhamos de par com o sucesso,

Trilhando a vereda do labor.

Formamos com luta e sacrifício,

Desta terra, a vanguarda industrial.

Somos todos irmãos em ofício,

Ansiando o Brasil sem igual.

Grande forja de homens viris,

Impressora fiel de idéias sãs,

Celeiro imenso de almas febris,

salve escola de jovens titãs;

A doce harmonia em nossa lida.

Ganha força à luz do saber.

Forma o ideal, a essência da vida,

Dotando o homem de energia e poder.

Continuemos a nossa jornada;

Por esse fértil campo de estudos.

Lutando e servindo a pátria amada,

Nossos peitos serão seu escudo.

E nós elevaremos a nação,

Hinos cantando cheios de vigor,

Renovando na sua construção.

As fontes do civismo e do valor.
A força que nossa voz encerra;
É o arrojo do nosso verde mar...
É o brilho, a beleza desta terra...
É a voz dum Brasil a caminhar. 
Aqui está evidente como a disseminação do ethos do trabalho se vinculava à virilidade masculina. Cabe perguntar como esses valores entravam na organização escolar e até que ponto se chocavam com a presença feminina a partir dos anos de $1970^{7}$. Mas, retomando o debate sobre o início da inserção feminina na instituição, a despeito dos documentos já apresentados, e por ter sido aluno de serralheria, o engenheiro e ex-diretor (1970-1994) Zenaldo Rosa da Silva (falecido em 20 de junho de 2020) afirma que a entrada das mulheres na ETFES teria ocorrido apenas em 1969. No seu relato, o fato teria ocorrido, apenas e tão somente porque ele, na condição de diretor, de modo inédito, teria apoiado e autorizado a matrícula de uma aluna de nome Ângela Mattos no curso de Edificações, inaugurando assim a inserção das mulheres na instituição (apud Lima, 2010). Resta saber se Zenaldo buscou esconder a inserção anterior das mulheres na instituição ou se ele tentou capitalizar para sua gestão o ineditismo dessa mesma inserção.

Confirmando parcialmente essa informação, temos a ficha escolar de Ângela Maria Firme Mattos, filha de Walter Coutinho Mattos e Gilcéa Firme Mattos, nascida em 2 de agosto de 1950, matriculada em 1970 no curso de Edificações. Apesar das notas 60 em português, 50 em matemática e 90 em geografia/história, a referida aluna foi reprovada na $1^{\text {a }}$ série em 1970, conforme mostram as Figuras 13,14 e $15^{8}$.

Na Figura 15, observa-se que, tendo sido reprovada em 5 de maio de 1971, a aluna mencionada protocolou um pedido ao diretor Zenaldo Rosa da Silva para permanecer no curso em 1971. No documento fica explícito que ela pertencia ao $1^{\circ}$ ano do colegial técnico em Edificações e, "não tendo conseguido aprovação no referido ano, requeria que lhe fosse concedida a matrícula".

Contrastando, no entanto, essa informação com Lima (2010), encontramos a Figura 16, imagem na qual figuram mulheres já em 1966. Trata-se de, pelo menos, três alunas enfileiradas em situação de pose, na ocasião de hasteamento da bandeira. Tal documento diverge da informação anterior, pois a datação da foto se contrapõe às fontes anteriores. Destarte, se o curso de Estradas foi criado na escola em 1961 (ver jornal Gitec), entendemos que ambas as fontes precisam ser cotejadas com outras para saber o motivo de a discente Ângela Mattos ser considerada a pioneira.

Metodologicamente, operando com o intercruzamento das fontes, na trilha de Ginzburg (1989) e Pinsky e Luca (2009), se as fotografias não são suficientes,

7 Mesmo tendo extinguido o internato no momento de reinserção das mulheres, a ETFES guardava muitas semelhanças com o estabelecimento militar. Segundo Sueth et al. (2009, p. 111), "era tão grande a rigidez da disciplina que" as mulheres, até 1980, "só podiam colocar no cabelo enfeites de cor preta”. Esse traço masculino da instituição preservou-se ainda em 1988, com 72,96\% das matrículas aos pertencentes ao sexo masculino.

8 Considerando o período em que ocorreram esses fatos, não foi possível obtermos autorização da aluna para confirmar esses dados. De qualquer forma, julgamos que essas informações não desmerecem a pessoa da aluna. Ao contrário, remetem ao papel pioneiro de aluna na instituição. Apoiamo-nos aqui na legislação decorrente da ADI 4.815 (apud Tomaz e Porto, 2015), que autoriza a produção de biografias. 


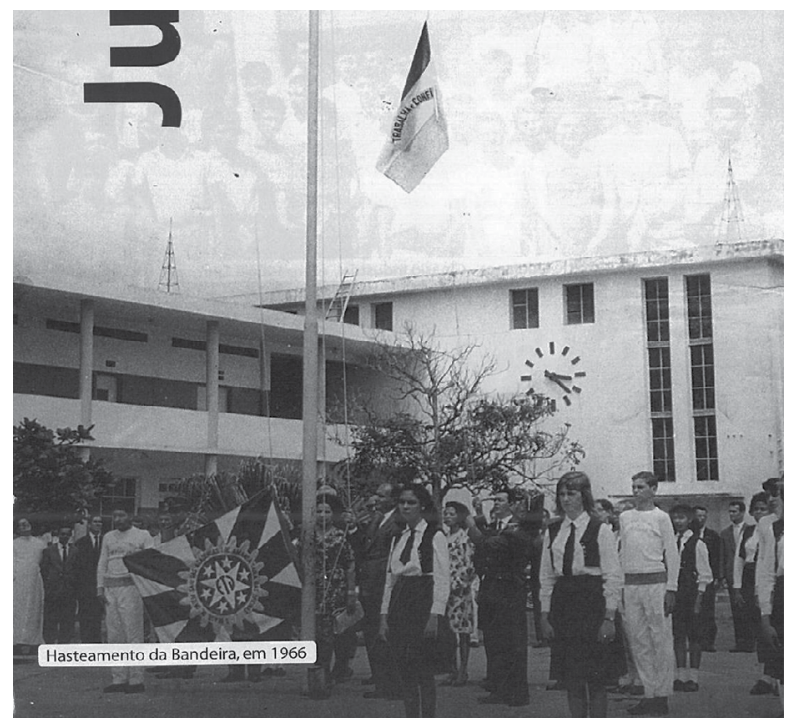

Figura 16 - Hasteamento da bandeira na Escola Técnica de Vitória em 1966, localizada no bairro de Jucutuquara, Vitória, Espírito Santo. Autor desconhecido.

Fonte: Sueth et al. (2009).

tampouco podem ser desprezadas. A imagem presente no acervo e em agenda comemorativa do Cefetes à época do centenário traz a bandeira da ETV e estão presentes nela pessoas do sexo feminino - trata-se do ano de 1966. Portanto, a oferta do ensino técnico com segundo grau, definida pela Lei no 5.692/1971, deve ter favorecido a inserção das mulheres na ETFES, mas não foi nesse momento que se deu a inserção das mulheres no ensino industrial no caso em estudo.

\section{CONCLUSÃO}

Neste trabalho analisamos a inserção da mulher na sociedade brasileira haja vista a sua inserção na educação, com base em elementos empíricos do acesso feminino ao ensino industrial em cursos oferecidos em unidades de ensino da rede federal, problematizando sua ocorrência no período de 1950 a 1970. Para realizar o debate sobre a inserção feminina no ensino industrial na história do Brasil, mobilizamos elementos históricos e historiográficos da trajetória do IFES, que nos anos de 1970, fase em que a instituição se denominava Escola Técnica Federal do Espírito Santo, contava com a presença mais expressiva de mulheres entre seus educandos.

Com o objetivo de questionar a periodização oficial segundo a qual mulheres teriam se inserido apenas a partir dos anos de 1970 na chamada ETFES, em razão da criação dos cursos técnicos de segundo grau, percorremos as fontes históricas disponíveis nos acervos da instituição. Nesse movimento evidenciamos, por um lado, a complementariedade dos tipos de fontes históricas e, por outro, problematizamos os limites da validade da fotografia como fonte histórica. 
O uso da fotografia como fonte histórica está sujeito a inúmeras escolhas conscientes e direcionadas tanto à produção quanto ao manuseio e/ou à preservação de documentos que vão servir como monumentos para se produzir ou apagar um conjunto de fontes constitutivas de determinada memória.

Acreditamos, com base no exposto, que o apagamento e a negação da inserção das mulheres nos cursos do ensino industrial na referida instituição antes dos anos de 1970 só podem ser desvelados no cotejamento das fontes e na problematização do uso da fotografia como fonte histórica. A análise das fontes permitiu revelar que na escola estudaram outras alunas ainda nos anos de 1950, mas que teriam sido tão sistematicamente reprovadas e excluídas que, na virada da década de 1960 para a de 70, a inserção delas foi creditada como ação inédita e benevolente dos gestores de plantão.

De todo modo, a imagem hegemônica da ETFES continua masculina, machista e militarizada, com valores correcionais e meritocráticos. Organizados com rigor, o currículo escolar e os espaços-tempos da instituição não evidenciam as muitas contradições que constituem sua trajetória. A instituição, no seu hino e na sua imagem masculinizada e taylorizada, não assume a exclusão sistemática das mulheres nos anos de 1950 . Hoje, as políticas de cotas sociais e raciais, bem como os cursos de qualificação para jovens e adultos, causam incômodo por inserirem personagens estranhas à instituição, que deveria ser plenamente pública, e não apenas de qualidade.

Desse modo, com base no cruzamento de fontes documentais nas quais se incluem fotografias e demais registros, destacamos os limites da escolha de fontes específicas isoladas e apontamos as contradições da versão assumida pela historiografia oficial, segundo a qual a inserção feminina na antiga ETV teria se iniciado apenas nos anos de 1970, por ocasião da criação dos cursos técnicos. A interlocução de documentos negligenciados na versão hegemônica, mas ainda existentes, entretanto, confirma a presença das mulheres no ensino industrial na ETV, ainda em 1950. Esse público foi excluído, provavelmente, por mecanismos de meritocracia e seletividade, nos quais se atribuía aos educandos, sobretudo às educandas, a responsabilidade pela sua própria aprendizagem. Tal processo foi tão eficaz que, ao chegar aos anos de 1960, não havia mais nenhuma mulher nos bancos da ETV. Já na ETFES as mulheres foram reinseridas como se nunca ali tivessem entrado, razão pela qual se constituiu uma memória oficial segundo a qual a presença feminina teria se iniciado apenas com o advento da denominação de ETFES, com a oferta dos cursos técnicos, o que só a busca sistemática e a interlocução de fontes podem superar. Vale perguntar: como esse processo se deu em outras unidades centenárias da rede federal que hoje compõem unidades dos institutos federais?

\section{REFERÊNCIAS}

BENJAMIN, W. Magia e técnica, arte e política. 7. ed. São Paulo: Brasiliense, 1987. BLOCH,M. Apologia da história ou o ofício do historiador. Rio de Janeiro: Zahar, 2001. BOTHÉQUIA, R. et al. O visgo eteviano. Vitória: ETFES, 1979.

BRASIL. Decreto no 7.247, de 19 de abril de 1879. Brasil, 1879. Disponível em: https:// ead2.iff.edu.br/mod/url/view.php?id=106376. Acesso em: 4 jul. 2019. 
BRASIL.Decreto-lei n 4.073, de 30 de janeiro de 1942. Diário Oficial daUnião,30 jan.1942. BRASIL. Lei no 378, de 13 de janeiro de 1937. Dá nova organização ao Ministério da educação e Saúde Pública. Diário Oficial da União, Seção 1, 15 jan. 1937.

BRASIL. Lei no 5.692, de 11 de agosto de 1971. Fixa Diretrizes e Bases para o ensino de $1^{\circ}$ e $2^{\circ}$ graus, e dá outras providências. Brasília, 1971.

BRASIL. 100 anos da rede federal. Brasília, MEC, 2009. Disponível em: http:// centenariorede.mec.gov.br/index.php/fotos. acesso em: maio 2019.

CIAVATTA, M. Mediações históricas de relação trabalho e educação: gênese da disputa na formação dos trabalhadores (1930-1960). Rio de Janeiro: Lamparina/CNPq/Faperj, 2004.

FERREIRA, M.J. R. Interdições e resistências: os difíceis percursos da escolarização das mulheres na EPT. 285f. Tese (Doutorado em Educação) - Programa de PósGraduação em Educação, Universidade Federal do Espírito Santo, Vitória, 2017.

FONTES, V.História e verdade. In: FRIGOTTO, G.; CIAVATTA, M. (org.). Teoria e educação no labirinto do capital. 2. ed. São Paulo: Expressão Popular, 2014. p. 167-189. GINZBURG, C. Mitos, emblemas, sinais: morfologia e história. Tradução: Federico Carotti. São Paulo: Companhia das Letras, 1989.

HOBSBAWM, E. O presente como história. In: HOBSBAWM, E. Sobre história. São Paulo: Companhia das Letras, 2003. p. 315-331.

KOSIK, K. Dialética do concreto. 2. ed. São Paulo: Paz e Terra, 1976.

KOSSOY, B. Fotografia e história. São Paulo: Ática, 1998.

KOSSOY, B. Realidades e ficções na trama fotográfica. 2. ed. São Paulo: Ateliê, 2000. LE GOFF, J. História e memória. São Paulo: Editora da Unicamp, 1996.

LIMA, M. Desenvolvimento histórico do tempo socialmente necessário para a formação professional. Vitória, 2010.

MACHADO, A. A fotografia sob o impacto da eletrônica. In: SAMAIN, E. (org.). O fotográfico. São Paulo: Hucitec, 1998. p. 317-325.

MALERBA, J. Teoria e história da historiografia. In: MALERBA, J. Teoria e história da historiografia. São Paulo: Contexto, 2006. p. 11-26.

MAUAD, A.M.Poses eflagrantes: ensaios sobre história e fotografia. Niterói:EDUFF,2008. PINTO, A. H. Educação matemática e formação para o trabalho: práticas escolares na Escola Técnica de Vitória — 1960 a 1990. Tese (Doutorado em Educação) - Faculdade de Educação, Universidade Estadual de Campinas, Campinas, 2006.

PINSKY,C. B.;LUCA,T.R.(org.). Ohistoriador e suas fontes. São Paulo: Contexto, 2009.

SAFFIOTI, H. A mulher na sociedade de classes: mito e realidade. São Paulo: Expressão Popular, 2013.

SANTOS, B. S. Um discurso sobre as ciências na transição para uma ciência pósmoderna. Estudos Avançados, São Paulo, v. 2, n. 2, maio/ago. 1988. https://doi. org/10.1590/S0103-40141988000200007

SOUSA,J.T.de.A memória da educação profissional e tecnológica no IFES: caminhos para acesso e difusão das fontes documentais no campus Vitória. Dissertação (Mestrado em Educação 
Profissional e Tecnológica) - Programa de Pós-Graduação em Educação Profissional e Tecnológica,Instituto Federal do Espírito Santo, Vitória,2019.Disponível em: http://biblioteca. ifes.edu.br:8080/pergamumweb/vinculos/000018/00001819.pdf. Acesso em: dez. 2019.

SOUZA, R. M. F. História da organização do trabalho escolar e do currículo no século XX (ensino primário e secundário no Brasil). São Paulo: Cortez, 2008.

SUETH, X. et al. 100 anos dos jovens titãs. Vitória: Edifes, 2009.

TOMAZ,L.C.L.; PORTO, P.O Supremo Tribunal Federal e a permissão para publicações de biografias não autorizadas: uma análise da ADIN 4815.Jus, 2015.Disponível em: https:// jus.com.br/artigos/62181/o-supremo-tribunal-federal-e-a-permissao-para-publicacoes-debiografias-nao-autorizadas-uma-analise-da-adin-4815. Acesso em: dez. 2019.

\section{SOBRE OS AUTORES}

Marcelo Lima é doutor em educação pela Universidade Federal Fluminense (UFF). Professor da Universidade Federal do Espírito Santo (UFES). E-mail:marcelo.lima@ufes.br

Lisia Nicoliello Cariello é mestranda em história pela Universidade Federal Fluminense (UFF).

E-mail: lisiacariello@hotmail.com

Rosângela Aquino da Rosa é doutora em educação pela Universidade Federal Fluminense (UFF). Professora do Instituto Federal de Educação, Ciência e Tecnologia do Rio de Janeiro (IFRJ).

E-mail: rosangelrosa@gmail.com

Conflitos de interesse: Os autores declaram que não possuem nenhum interesse comercial ou associativo que represente conflito de interesses em relação ao manuscrito.

Financiamento: $\mathrm{O}$ estudo não recebeu financiamento.

Contribuições dos autores: Conceituação: Lima, M.; Cariello, L. N.; Rosa, R. A.

Recebido em 31 de agosto de 2020 Aprovado em $1^{\circ}$ de fevereiro de 2021 